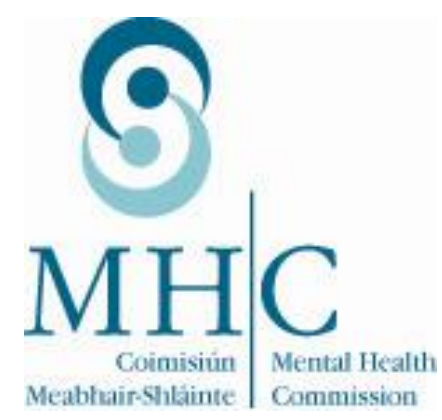

\title{
The Administration of Electro-convulsive Therapy in Approved Centres:
}

Activity Report 2010 


\section{Table of Contents}

Summary

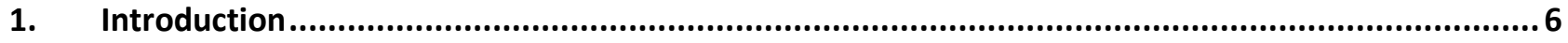

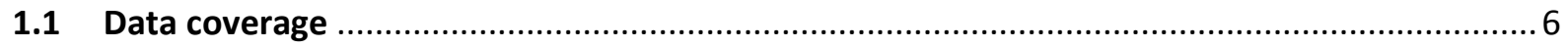

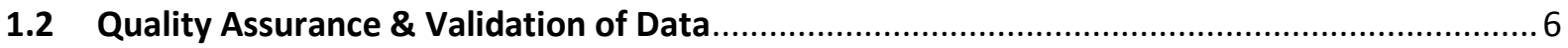

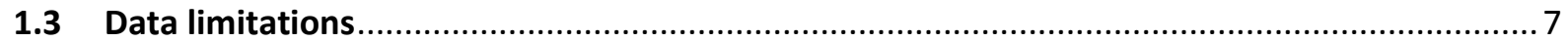

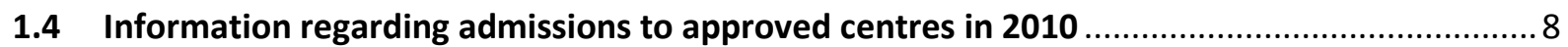

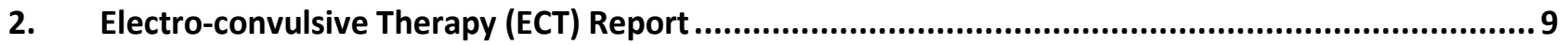

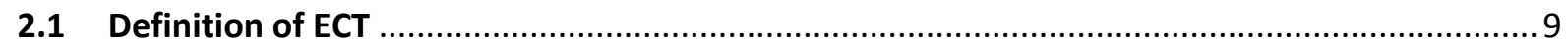

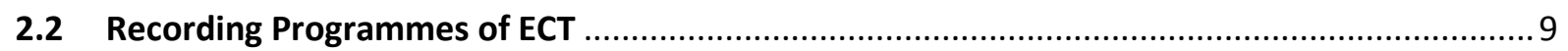

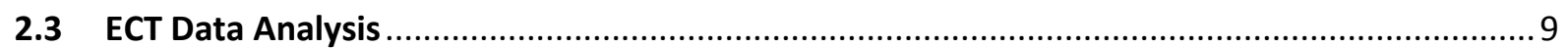

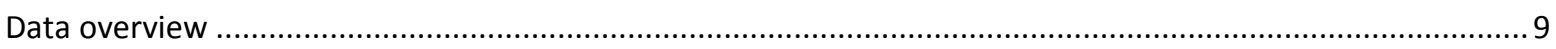

Programmes of ECT administered to Individuals and Number of Treatments per Programme ...................... 10

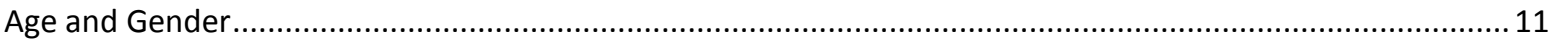

Administration of ECT by Super Catchment Area, Approved Centre and Service Type .................................. 11

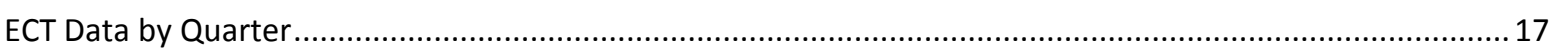

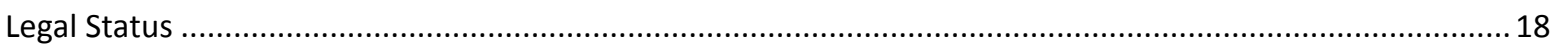

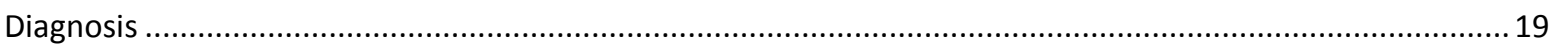

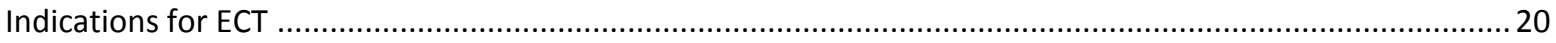

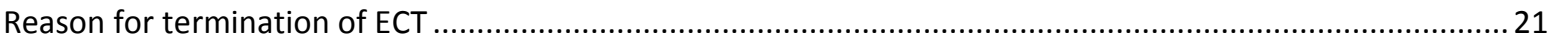

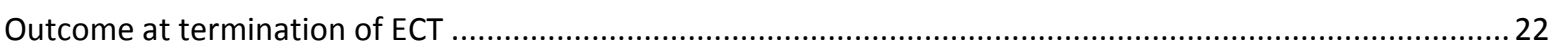

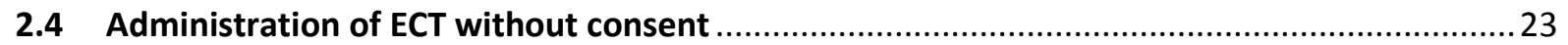

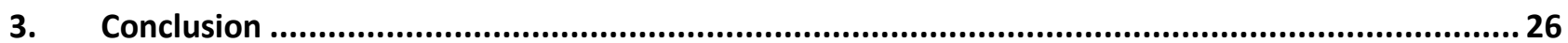

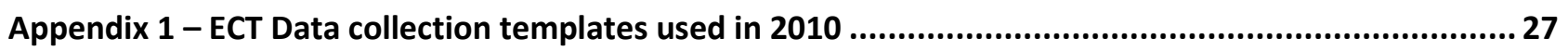

Appendix 2 - Overview of 2008, 2009 and 2010 Data Returns .............................................................. 29

Appendix 3 - Population by Super-Catchment Area ................................................................................ 32

Appendix 3 - Population by Super-Catchment Area …...................................................................... 32

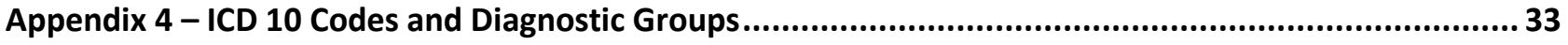




\section{List of Tables}

Table 1: Number of Involuntary admissions by quarter in 2010 .

Table 2: Overview of 2008, 2009 and 2010 data returns for All Approved Centres. Numbers and

Percentages.

Table 3: Administration of ECT in Approved Centres in 2008, 2009 and 2010. Mean and median treatments per programme of ECT.

Table 4: Age Group and Gender of individuals administered ECT in 2010.

Table 5: Administration of ECT in Approved Centres in 2008, 2009 and 2010. Numbers and percentage change between 2009 and 2010. Bed Numbers and Admissions (with Depressive Disorder admissions) in 2010.

Table 6: Approved Centres that reported administration of ECT without consent in 2010.

Table 7: Patient unable or unwilling to give consent. Number and percentage of Form 16 s returned to the Commission in 2010. .25

Table A1: Type of ECT data return by Approved Centres in 2008, 2009 and 2010. 29

\section{List of Figures}

Figure 1: Administration of ECT. Number of Treatments, Programmes and Residents by Quarter in 2010. .17 Figure 2: Legal Status of Residents that were administered ECT in 2008, 2009 and 2010 percentage of residents by Quarter. 18

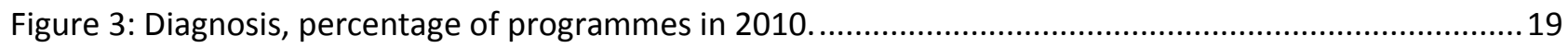

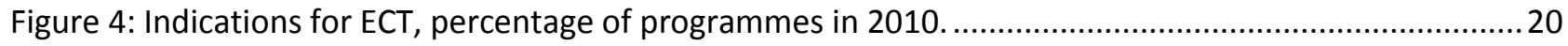

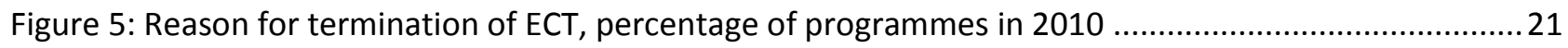

Figure 6: Outcome at termination of ECT, percentage of programmes in 2010 .........................................22 


\section{Summary}

This activity report includes data reported to the Mental Health Commission on the administration of ECT during 2010. Data are presented based on returns from 67 approved centres.

Twenty-three approved centres (34.3\%) indicated that ECT was administered to their residents in the approved centre. Seven approved centres (10.4\%) indicated that they referred residents to other approved centres for the administration of ECT.

A total of 347 programmes of ECT were reported to the Commission in 2010 which is equivalent to a rate of 8.2 programmes per 100,000 total population. There has therefore been a decrease of 26 compared to the number of ECT programmes administered in 2009.

In 2010, the majority of residents were administered one programme of ECT. The mean number of treatments per programme of ECT was 6.8 and the median number of treatments was seven.

As reported in 2008 and 2009, St Patrick's Hospital recorded the highest number of programmes of ECT (117/347) of all approved centres. It accounts for slightly more than a third (33.7\%) of all ECT programmes reported to the Commission. It is followed by the Department of Psychiatry at Waterford Regional Hospital (12.1\%) and St Brigid's Hospital in Ballinasloe (6.6\%).

In all quarters, the proportion of residents that were administered ECT who were voluntary patients was greater than $80 \%$.

Depressive disorders continue to be indicated as the diagnostic group that applies to a large majority (84.3\%) of ECT programmes. This diagnostic grouping was followed by Schizophrenia (8.2\%) and Mania (3.9\%).

Data on indications for ECT show that "refractory to medication" was by far the most prevalent indication. It accounted for almost $60 \%$ of all programmes of ECT and was followed by "multiple indications" (17.5\%) and "rapid response required" (14.7\%).

The consultant psychiatrist responsible for the care and treatment of the resident is required to indicate an outcome at the termination of an ECT programme. In 2010, some level of improvement was indicated for the overwhelming majority (94.7\%) of ECT programmes. For more than four out of ten $(43.2 \%)$ programmes, the responsible consultant psychiatrist recorded a "significant improvement". The second most common outcome was "complete recovery" (31.2\%).

"Improvement" was indicated as the reason for the termination of $86.8 \%$ of ECT programmes in 2010, making it by far the most common reason for bringing a aprogramme to an end. The next most popular reason for the termination of an ECT programme was that the patient withdrew his or her consent which occurred for $5.0 \%$ of programmes.

Thirty-five programmes (10.1\%) of ECT that were administered to residents in approved centres in 2010 were administered to involuntary patients who were either unable or unwilling to give consent. There has therefore been a decrease in the number (44) and percentage (11.8\%) of programmes of ECT that were administered without patient consent in 2009.

Twenty approved centres (29.8\%) reported administration of ECT without consent to the Commission in 2010. 
The Mental Health Commission also receives data recorded on "Form 16s" related to the administration of ECT without consent. On more than two-thirds (67.5\%) of the "Form 16s" submitted to the Commission in 2010 , both consultant psychiatrists indicated that the patient was unable to give consent. For $12.5 \%$ of these Forms $16 \mathrm{~s}$, both consultant psychiatrists indicated that the patient was unwilling to give consent. 


\section{Introduction}

This is the Mental Health Commission's third annual report on the use of ECT in approved centres. The Administration of Electro-convulsive Therapy in Approved Centres: Activity Report 2010 is based on data provided to the Commission by approved centres in accordance with the Rules Governing the use of Electroconvulsive Therapy (MHC, 2009) and the Code of Practice on the Use of Electro-Convulsive Therapy for Voluntary Patients (MHC, 2009).

These Rules and Code regulate the administration of ECT in approved centres. Updated versions of both the Rules and the Code of Practice came into effect on $1^{\text {st }}$ January 2010.

This report describes the administration of ECT in 2010 nationally, regionally (by super-catchment area) and in individual services. Data are also compared with those from previous years and in particular with data from 2009. Care should be taken when interpreting changes in the administration of ECT from 2008 to 2010 as these are short term trends.

Some changes have been made to the report format this year. In particular, we present data on the administration of ECT to individual patients.

\subsection{Data coverage}

We present data for all centres which were entered on the Register of Approved Centres during 2010 and which were accepting admissions during the year ${ }^{1}$. Sixty-eight approved centres were therefore eligible for inclusion in this year's report. However, the report only includes complete data for 67 out of 68 approved centres as The Haven Children's Residential Unit did not return any 2010 data. This approved centre only had admissions in January and did not have any admissions for the remainder of the year.

\subsection{Quality Assurance \& Validation of Data}

- Data are required in four quarterly reports during the year. Data are manually extracted locally from the ECT Register and returned to the Mental Health Commission in aggregate format using the template as shown in Appendix 1. Collecting data on a quarterly basis facilitates the data collation and validation process.

- In addition to the quarterly reports, approved centres that administered ECT are asked to complete a report on administration of ECT to individual patients ${ }^{2}$ (see template in Appendix 1). The purpose

\footnotetext{
${ }^{1}$ Four approved centres were entered on the Register of Approved Centres in 2010. These were: Lois Bridges (January 2010), Willow Grove Adolescent Unit, St Patrick's University Hospital (April 2010) and the Child \& Adolescent Mental Health In-patient Unit, Merlin Park University Hospital and Eist Linn Child \& Adolescent In-patient Unit (both in December 2010). Although the Child \& Adolescent Mental Health In-patient Unit, Merlin Park University Hospital and Eist Linn Child \& Adolescent In-patient Unit were registered in 2010, they did not accept admissions until 2011 and therefore are not included in this report. Two approved centres ceased to operate in 2010. They were Unit 9A Merlin Park (May 2010) which no longer met the definition of an approved centre and St Conal's Hospital (June 2010) which closed.

${ }^{2}$ This report was also requested in 2009, however due to missing data and validation issues it was not possible to include these data in the 2009 ECT activity report.
} 
of this report is to enhance the aggregate summary data to enable us to report on the number of individuals that were administered ECT. These data were verified against the quarterly data returns.

- Inspection reports for 2010 are crossed checked with the data returns. If an approved centre had reported Nil Returns but the 2010 inspection report indicated that the centre did not use ECT, clarification was sought from the centre.

- A draft annual report based on the four quarterly reports and the report on administration of ECT to individual patients is sent to Clinical Directors in approved centres for verification. They are then requested to sign off on the data. At the time of writing this report one approved centre's data remained unverified. On the assumption that the approved centre in question would have communicated any inaccuracy applying to the data, the data for this centre has been taken as correct.

- The individual's right to privacy, dignity and autonomy are central to the operations of the Commission. Therefore, quarterly data were requested in aggregate format with no individual patient identifiers included. Patient Identifiers were disassociated from data returned in relation to administration of ECT to individual patients.

\subsection{Data limitations}

- Approved Centres vary in size and the type of service they deliver. Therefore, comparative analysis between Approved Centres is crude (For information regarding individual services, see the Mental Health Commission's Approved Centre Inspection Reports 2010 which can be accessed at www.mhcirl.ie.).

- As the quarterly data are returned in aggregate format with no individual patient identifiers (to protect the individual's right to privacy). This limits the extent of data analysis that can be carried out.

- Data on the administration of ECT are processed manually which limits what we can reasonably request from services. A national mental health information system would enable the Commission to request additional information that would facilitate enhanced patient and outcomes focused reporting. This would give us a more complete view of the use of ECT in Ireland and allow us to carry out more detailed comparisons of national data with international data.

- There is a dearth of current published ECT data from other jurisdictions. Therefore, it is difficult to compare the administration of ECT in Ireland in $\mathbf{2 0 1 0}$ with other countries. Scotland has published $2010 \mathrm{ECT}$ data ${ }^{3}$ and where appropriate, these data are referred to in this report.

In 2010, three approved centres included data on the administration of ECT to individuals on an outpatient basis in their returns ( $n=12$ programmes of ECT). As we do not have comprehensive national data on the administration of ECT to outpatients in 2010 these programmes of ECT have not been included in this report.

${ }^{3}$ Scottish ECT Accreditation Network (2011), Annual Report 2011: A summary of ECT in Scotland for 2010 (Edinburgh: NHS National Services Scotland). 


\subsection{Information regarding admissions to approved centres in 2010}

Information regarding admission activity in 2010 may provide some context in relation to the administration ECT in approved centres.

The following information was reported by the Health Research Board ${ }^{4}$ :

- There were 19,619 admissions to approved centres in 2010 which is equivalent to a rate of 462.7 per 100,000 population.

- There was an equal proportion of male and female admissions and the admissions rates were similar for both at 464.6 per 100,000 population for males and 460.9 per 100,000 population for females.

- Depressive disorders accounted for $29 \%$ of admissions and schizophrenia accounted for $19.5 \%$ of admissions in 2010.

- The HSE South region had the highest rate of all admissions, at 496.6 per 100,000 , followed by HSE West, at 462.8 per 100,000 population and Dublin North-East, at 447.2 per 100,000 population. Dublin Mid-Leinster had the lowest rate of all admissions, at 439.9 per 100,000 population.

- Admission rates were highest in Waterford Mental Health Catchment Area, at 553.1 per 100,000 population, followed by Dublin North (538.2) and Kerry (532.1). Cavan/Monaghan had the lowest rate of all admissions, at 142.3 per 100,000 population, followed closely by Cluain Mhuire MHCA (142.7).

Table 1 shows the number of involuntary admissions (Form 6 admissions and Form 13 re-grade of a voluntary patient) of adults reported by the Mental Health Commission ${ }^{5}$ in 2010.

Table 1: Number of Involuntary admissions by quarter in 2010.

(Form 6 admissions and Form 13 re-grades of voluntary patients)

\begin{tabular}{|c|c|c|c|c|}
\hline Q1 & Q2 & Q3 & Q4 & TOTAL \\
\hline 466 & 536 & 503 & 447 & 1952 \\
\hline
\end{tabular}

Note: Mental Health Commission data regarding involuntary admissions includes Form 13 re-grades of voluntary patients, whereas the Health Research Board report on legal status as recorded on admission.

\footnotetext{
${ }^{4}$ Health Research Board (2011), HRB Statistics Series 15 Activities of Irish Psychiatric Units and Hospitals 2010. (Dublin: HRB).

${ }^{5}$ Mental Health Commission. Mental Health Tribunals Activity Statistics 2010 from http://www.mhcirl.ie.
} 


\section{Electro-convulsive Therapy (ECT) Report}

\subsection{Definition of ECT}

ECT is a medical procedure in which an electric current is passed briefly through the brain via electrodes applied to the scalp to induce generalised seizure activity. The person receiving treatment is placed under general anaesthetic and muscle relaxants are given to prevent body spasms. Its purpose is to treat specific types of major mental illnesses ${ }^{6}$.

\subsection{Recording Programmes of ECT}

The Rules and Code of Practice Governing the Use of Electro-convulsive Therapy prescribe that the ECT Register must be completed for the patient/voluntary patient on conclusion of a programme ${ }^{7}$ of ECT and a copy filed in the patient's/voluntary patient's clinical file. As a programme of ECT may have been commenced in one quarter and completed in another, each programme is counted in the quarter in which it was concluded as this is when the ECT register is completed in full.

\subsection{ECT Data Analysis}

\section{Data overview}

Data are presented for all of 2010 and for each quarter as appropriate. Data on the number of programmes of ECT administered are presented nationally, by super catchment area, by service type and by individual approved centre.

Table 2 shows that $24(35.8 \%)$ approved centres $(n=67)$ reported positive ECT returns in 2010 . However ECT was only administered in 23 centres; one centre referred their patients to another centre for treatment but made their own data returns, as was the case in 2008 and 2009. The same 24 centres reported positive returns in 2009 and 2010. There was an increase in the number of approved centres that indicated they do not administer ECT from 31 to 34 . This increase can be partly attributed to enhanced data validation whereby 2010 data returns were cross checked with 2010 inspection reports to ensure accurate reporting. Six approved centres referred patients to other approved centres for the administration of ECT and the treating centre included them in their data returns. See Table A1, Appendix 2 for details of data returned by individual approved centres).

\footnotetext{
6 "mental illness" means a state of mind of a person which affects the person's thinking, perceiving, emotion or judgment and which seriously impairs the mental function of the person to the extent that he or she requires care or medical treatment in his or her own interest or in the interest of other persons.

${ }^{7}$ A programme of ECT refers to no more than 12 treatments prescribed by a consultant psychiatrist.
} 
Table 2: Overview of 2008, 2009 and 2010 data returns for All Approved Centres. Numbers and Percentages.

\begin{tabular}{|l|c|c|c|c|c|}
\cline { 2 - 5 } \multicolumn{1}{c|}{} & \multicolumn{4}{c|}{ Data return type } & \multicolumn{1}{c|}{} \\
\hline Year & $\sqrt{ }$ & NR & DNA & Ref O/AC & Total \\
\hline 2008 & $24(37.5 \%)$ & $12(18.75 \%)$ & $28(43.75 \%)$ & $a$ & 64 \\
\hline 2009 & $24(36.4 \%)$ & $8(12.1 \%)$ & $31(47.0 \%)$ & $3(4.5 \%)$ & 66 \\
\hline 2010 & $24(35.8 \%)$ & $3(4.5 \%)$ & $34(50.7 \%)$ & $6(9.0 \%)$ & 67 \\
\hline
\end{tabular}

a These data were not available for inclusion in the 2008 Activity Report.

Notes: $\quad \sqrt{ }=$ Positive data returns

$\mathbf{N R}=$ Nil returns (indicated zero administration of ECT)

DNA = Do not administer (indicated that they do not administer ECT in their centre)

Ref $\mathrm{O} / \mathrm{AC}=$ Patients referred to another approved centre for administration of ECT and data was reported by the approved centre that administered ECT.

\section{Programmes of ECT administered to Individuals and Number of Treatments per Programme}

There were 347 programmes of ECT administered in 2010. This represents a rate of 8.2 programmes per 100,000 total population. There was a decrease of 26 programmes of ECT on the number of programmes reported in 2009 ( $n=373$ ) and a decrease of 60 programmes on the number of programmes reported in $2008(n=407)$.

Data on administration of ECT to individual patients reported that 260 individuals were administered $296^{8}$ programmes of ECT in 2010.

The number of programmes administered to an individual in 2010 ranged from one programme to three programmes. The majority of individuals, $87.5 \%\left(n=197 / 225^{9}\right)$ were administered one programme of ECT, $11.5 \%(n=26 / 225)$ were administered two programmes of ECT and three programmes of ECT were administered to $1 \%(n=2)$ of patients.

Table 3 shows that there continues to be little variation from year to year in the average number of treatments administered to patients during a programme of ECT. In 2010, the mean number of treatments per programme of ECT was 6.8 and the median was seven. In Scotland in $2010^{10}$, the mean number of treatments per programme (episode) reported was 8.2 and the median was eight.

\footnotetext{
${ }^{8}$ Data on administration of ECT to individual patients were not available in relation to 51 programmes of ECT.

${ }^{9}$ Two approved centres included data on administration of ECT to outpatients but did not identify which records related to inpatients and which records related to outpatients therefore their data has been excluded.

${ }^{10}$ Scottish ECT Accreditation Network (2011), Annual Report 2011: A summary of ECT in Scotland for 2010 (Edinburgh: NHS National Services Scotland).
} 
Table 3: Administration of ECT in Approved Centres in 2008, 2009 and 2010. Mean and median treatments per programme of ECT.

\begin{tabular}{|l|c|c|c|}
\hline Year & Mean Treatments per Programme & Median Treatments per Programme & Total Treatments \\
\hline 2008 & 6.7 & 7 & 2,725 \\
\hline 2009 & 7.2 & 7 & 2,672 \\
\hline 2010 & 6.8 & 7 & 2,349 \\
\hline
\end{tabular}

\section{Age and Gender}

The majority (64\%) of individuals, who were administered ECT in 2010, were in the 18-64 years of age group (see Table 4). Ages ranged from 20 years of age to 90 years of age. The overall mean age was 57 and the median age was 58. For females, the mean age was 59 and the median age was 60 . For males, a mean age of 54 and a median age of 56 were recorded. These figures are similar to what was reported in Scotland ${ }^{11}$ in the same period where the median age for women was 59 and the median age for men was 57.

The overall female to male ratio was roughly 2:1; however in the 65 years of age and older age group it was 3:1.

Table 4: Age Group and Gender of individuals administered ECT in 2010.

\begin{tabular}{|l|c|c|c|}
\cline { 2 - 4 } \multicolumn{1}{c|}{} & \multicolumn{2}{c|}{ Gender } & Male \\
\hline Age Group & Female & 51 & Total \\
\hline 18-64 years of age & 93 & 20 & 144 \\
\hline Total years or older & 61 & $\mathbf{7 1}$ & 81 \\
\hline
\end{tabular}

a Two approved centres included data on administration of ECT to outpatients but did not identify which records related to inpatients and which records related to outpatients therefore their data has been excluded.

\section{Administration of ECT by Super Catchment Area, Approved Centre and Service Type}

Table 5 shows the percentage change in number of programmes of ECT administered in 2008, 2009 and 2010 by approved centre. Data are also broken down by super-catchment area and service type. Only approved centres and super-catchment areas in which the administration of ECT was recorded during these three years are displayed in the table.

There was a large variance in the number of programmes of ECT administered by approved centres (see Table 5); this is consistent with what was reported in 2008 and 2009. When looking at these data, variables such as the number of beds in the approved centre, the total number of admissions and the number of

\footnotetext{
${ }^{11}$ Scottish ECT Accreditation Network (2011), Annual Report 2011: A summary of ECT in Scotland for 2010 (Edinburgh: NHS National Services Scotland).
} 
admissions with Depressive disorders ${ }^{12}$ may explain some of this variance; this information is included in Table 5.

There was also variance between approved centres regarding the mean number of treatments administered per programme of ECT ranging from 3.8 treatments in the South Lee Mental Health Unit, Cork University Hospital to 10.5 treatments in the Acute Psychiatric Unit, Cavan General Hospital.

St Patrick's Hospital reported the highest number of programmes of ECT $(n=117)$ accounting for a third (33.7\%) of all programmes of ECT. St Patrick's Hospital was the largest approved centre in 2010 (238 beds) and had the highest number of admissions ( $n=2,354)$. The Department of Psychiatry, Waterford Regional Hospital had the second highest number of programmes $(n=42)$ which represents $12.1 \%$ of all programmes; this approved centre is a 44-bed unit and reported 645 admissions in 2010. St Brigid's Hospital, Ballinasloe reported the next highest number of programmes of ECT ( $n=23)$ which is equivalent to $6.6 \%$ of all programmes of ECT. This approved centre is a 77-bed unit which had 412 admissions in 2010.

Eleven super-catchment areas reported they had administered ECT in 2010. Waterford/Wexford recorded the highest number of programmes of ECT $(n=53)$ which is equivalent to a rate of 20.7 per 100,000 population in 2010. The West (Galway/Mayo/Roscommon) super-catchment area reported the second highest number of programmes $(n=39)$ but Carlow/Kilkenny/ South Tipperary reported the second highest rate of programmes per 100,000 population (13.6). Rates per 100,000 population should be viewed with caution as they are a crude comparison of ECT usage between super catchment areas. It is important to note that almost $40 \%$ (37.5\%) of ECT in 2010 was administered by two approved centres in the independent sector that provide a national service. Furthermore, the majority of approved centres do not have an ECT service and therefore it is likely that some HSE patients were treated outside their own supercatchment area. In the absence of individual patient level data on home address, which would allow us to redistribute patients to their own super catchment area to calculate absolute rates, we recognise that super catchment rates per 100,000 population are an imperfect measure.

\footnotetext{
${ }^{12}$ Depression is the main indication for ECT therefore to better determine any variability in practice between individual treating centres, the number of patients receiving ECT should be looked at in the context of the number of admissions with depression to each centre. R Dunne, DM McLoughlin. Regional Variation in Electroconvulsive Therapy Use. Irish Medical Journal (April 2011).
} 
Table 5: Administration of ECT in Approved Centres in 2008, 2009 and 2010. Numbers and percentage change between 2009 and 2010. Bed Numbers and Admissions (with Depressive Disorder admissions) in 2010.

\begin{tabular}{|c|c|c|c|c|c|c|c|c|}
\hline Catchment Area & Approved Centre Name & $\begin{array}{l}\text { Number of } \\
\text { Programmes } \\
\text { of ECT in } 2008\end{array}$ & $\begin{array}{l}\text { Number of } \\
\text { Programmes } \\
\text { of ECT in } 2009 \\
\end{array}$ & \begin{tabular}{|c|} 
Number of \\
Programmes of \\
ECT in 2010 \\
\end{tabular} & Difference & $\begin{array}{c}\% \\
\text { Change }\end{array}$ & \begin{tabular}{|l|} 
Bed Numbers \\
in 2010
\end{tabular} & $\begin{array}{l}\text { Admissions } \\
\text { (Depressive disorders) } \\
\text { in } 2010 \\
\end{array}$ \\
\hline \multicolumn{9}{|c|}{ Dun Laoghaire, Dublin South-East \& Wicklow } \\
\hline Dublin South East & Elm Mount Unit, St Vincent's University Hospital & 12 & 8 & 8 & 0 & - & 39 & $328(78)$ \\
\hline East Wicklow & Newcastle Hospital & 4 & 2 & 3 & 1 & $50.0 \%$ & 55 & $360(120)$ \\
\hline \multicolumn{2}{|c|}{ Total Dun Laoghaire, Dublin South-East \& Wicklow } & 16 & 10 & 11 & 1 & $10.0 \%$ & & \\
\hline \multicolumn{2}{|c|}{$\begin{array}{l}\text { Total per } 100,000 \text { population Dun Laoghaire, Dublin South-East } \& \text { Wicklow (excludes } \\
\text { Cluain Mhuire }{ }^{13} \text { population) }\end{array}$} & 8.0 & 5.0 & 5.5 & & & & \\
\hline \multicolumn{9}{|c|}{ Dublin West/Dublin South West \& Dublin South City } \\
\hline Dublin South City & Jonathan Swift Clinic ${ }^{a}$ & 14 & 9 & 8 & -1 & $-11.1 \%$ & 51 & $431(101)$ \\
\hline Dublin South West & Acute Psychiatric Unit AMNCH (Tallaght) Hospital & 12 & 4 & 8 & 4 & $100.0 \%$ & 52 & $603(151)$ \\
\hline \multicolumn{2}{|c|}{ Total Dublin West/Dublin South West \& Dublin South City } & 26 & 13 & 16 & 3 & $23.1 \%$ & & \\
\hline \multicolumn{2}{|c|}{ Total per 100,00 population Dublin West/Dublin South West \& Dublin South City } & 6.7 & 3.3 & 4.1 & & & & \\
\hline \multicolumn{9}{|c|}{ Kildare/West Wicklow, Laois/Offaly \& Longford/Westmeath } \\
\hline $\begin{array}{l}\text { Kildare } \\
\text { West/Wicklow }\end{array}$ & Lakeview Unit, Naas General Hospital & 12 & 10 & 6 & -4 & $-40.0 \%$ & 29 & $428(72)$ \\
\hline Laois/Offaly & $\begin{array}{l}\text { Department of Psychiatry, Midland Regional Hospital, } \\
\text { Portlaoise }\end{array}$ & 4 & 15 & 5 & -10 & $-66.7 \%$ & 40 & $558(173)$ \\
\hline $\begin{array}{l}\text { Longford/ } \\
\text { Westmeath }\end{array}$ & St Loman's Hospital, Mullingar & 11 & 4 & 3 & -1 & $-25.0 \%$ & 108 & $530(138)$ \\
\hline \multicolumn{2}{|c|}{ Total Kildare/West Wicklow, Laois/Offaly \& Longford/Westmeath } & 27 & 29 & 14 & -15 & $-51.7 \%$ & & \\
\hline \multicolumn{2}{|c|}{$\begin{array}{l}\text { Total per } 100,000 \text { population Kildare/West Wicklow, Laois/Offaly \& } \\
\text { Longford/Westmeath }\end{array}$} & 5.9 & 6.3 & 3.1 & & & & \\
\hline
\end{tabular}

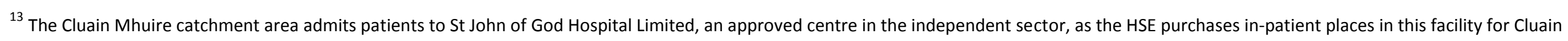
Mhuire patients. Data for the Dun Laoghaire/Dublin South East \& Wicklow super-catchment area do not include data from patients of the Cluain Mhuire (Dun Laoghaire) catchment area who may have been administered ECT in St John of God Hospital Limited as St John of God Hospital return all data in aggregate format without any differentiation between private and public patients. 


\section{Table 5 continued}

\begin{tabular}{|c|c|c|c|c|c|c|c|c|}
\hline Catchment Area & Approved Centre Name & $\begin{array}{l}\text { Number of } \\
\text { Programmes } \\
\text { of ECT in } 2008 \\
\end{array}$ & \begin{tabular}{|c} 
Number of \\
Programmes of \\
ECT in 2009 \\
\end{tabular} & \begin{tabular}{|c|} 
Number of \\
Programmes of \\
ECT in 2010 \\
\end{tabular} & Difference & $\begin{array}{c}\% \\
\text { Change } \\
\end{array}$ & $\begin{array}{c}\text { Bed } \\
\text { numbers in } \\
2010 \\
\end{array}$ & \begin{tabular}{|c} 
Admissions \\
$\begin{array}{c}\text { (Depressive disorders) } \\
\text { in } 2010\end{array}$ \\
\end{tabular} \\
\hline \multicolumn{9}{|c|}{ Cavan/Monaghan, Louth Meath } \\
\hline Cavan/Monaghan & Acute Psychiatric Unit, Cavan General Hospital ${ }^{b}$ & 0 & 3 & 2 & -1 & $-33.3 \%$ & 20 & $105(27)$ \\
\hline \multicolumn{2}{|c|}{ Total Cavan/Monaghan, Louth Meath } & 0 & 3 & 2 & -1 & $-33.3 \%$ & & \\
\hline \multicolumn{2}{|c|}{ Total per 100,000 population Cavan/Monaghan, Louth Meath } & - & 0.8 & 0.5 & & & & \\
\hline \multicolumn{9}{|c|}{ Dublin North Central/North West Dublin } \\
\hline Dublin North Central & St Aloysius Ward, Mater Misericordiae Hospital & 8 & 4 & 1 & -3 & $-75.0 \%$ & 15 & $218(35)$ \\
\hline Dublin North Central & St Vincent's Hospital $^{c}$ & 3 & 1 & 4 & 3 & $300.0 \%$ & 76 & $572(79)$ \\
\hline Dublin North West & St Brendan's Hospital $^{d}$ & - & 4 & 4 & 0 & - & 82 & $230(81)$ \\
\hline \multicolumn{2}{|c|}{ Total Dublin North Central/North West Dublin } & 11 & 9 & 9 & 0 & - & & \\
\hline \multicolumn{2}{|c|}{ Total per 100,000 population Dublin North Central/North West Dublin } & 3.5 & 2.9 & 2.9 & & & & \\
\hline \multicolumn{9}{|l|}{ North Lee/North Cork } \\
\hline North Cork & St Stephen's Hospital $^{\mathrm{e}}$ & - & - & 1 & 1 & - & 104 & $266(73)$ \\
\hline North Lee & Carraig Mór Centre ${ }^{\mathrm{e}}$ & - & - & 1 & 1 & - & 38 & $75(10)$ \\
\hline North Lee & St Michael's Unit, Mercy Hospital & 2 & 0 & 0 & 0 & - & 50 & $670(274)$ \\
\hline \multicolumn{2}{|c|}{ Total North Lee/North Cork } & 2 & 0 & 2 & 2 & - & & \\
\hline \multicolumn{2}{|c|}{ Total per 100,000 population North Lee/North Cork } & 0.8 & 0 & 0.8 & 0 & & & \\
\hline \multicolumn{9}{|c|}{ South Lee/West Cork/Kerry } \\
\hline Kerry & $\begin{array}{l}\text { Acute Mental Health Admission Unit, Kerry General } \\
\text { Hospital }\end{array}$ & 7 & 1 & 1 & 0 & - & 44 & $732(191)$ \\
\hline South Lee & South Lee Mental Health Unit, Cork University Hospital & 0 & 1 & 3 & 2 & $200.0 \%$ & 46 & $581(188)$ \\
\hline \multicolumn{2}{|c|}{ Total South Lee/West Cork/Kerry } & 7 & 2 & 4 & 2 & $100.0 \%$ & & \\
\hline \multicolumn{2}{|c|}{ Total per 100,000 population South Lee/West Cork/Kerry } & 1.9 & 0.5 & 1.1 & & & & \\
\hline \multicolumn{9}{|l|}{ Waterford/Wexford } \\
\hline Waterford & Department of Psychiatry, Waterford Regional Hospital & 27 & 26 & 42 & 16 & $61.5 \%$ & 44 & $645(172)$ \\
\hline Wexford & St Senan's Hospital & 13 & 7 & 11 & 4 & $57.1 \%$ & 85 & $560(167)$ \\
\hline \multicolumn{2}{|c|}{ Total Waterford/Wexford } & 40 & 33 & 53 & 20 & $60.6 \%$ & & \\
\hline \multicolumn{2}{|c|}{ Total per 100,000 population Waterford/Wexford } & 15.6 & 12.9 & 20.7 & & & & \\
\hline
\end{tabular}




\section{Table 5 continued}

\begin{tabular}{|c|c|c|c|c|c|c|c|c|}
\hline Catchment Area & Approved Centre Name & $\begin{array}{l}\text { Number of } \\
\text { Programmes } \\
\text { of ECT in } 2008 \\
\end{array}$ & $\begin{array}{c}\text { Number of } \\
\text { Programmes of } \\
\text { ECT in } 2009\end{array}$ & $\begin{array}{c}\text { Number of } \\
\text { Programmes of } \\
\text { ECT in } 2010 \\
\end{array}$ & Difference & $\begin{array}{c}\% \\
\text { Change }\end{array}$ & $\begin{array}{c}\text { Bed } \\
\text { numbers in } \\
2010 \\
\end{array}$ & $\begin{array}{c}\text { Admissions } \\
\text { in } 2010 \\
\end{array}$ \\
\hline \multicolumn{9}{|c|}{ Carlow/Kilkenny/South Tipperary } \\
\hline Carlow/Kilkenny & Department of Psychiatry, St Luke's Hospital, Kilkenny & 9 & 8 & 17 & 9 & $112.5 \%$ & 44 & $473(93)$ \\
\hline South Tipperary & St Michael's Unit, South Tipperary General Hospital & 8 & 12 & 11 & -1 & $-8.3 \%$ & 49 & $716(388)$ \\
\hline \multicolumn{2}{|c|}{ Total Carlow/Kilkenny/South Tipperary } & 17 & 20 & 28 & 8 & $40.0 \%$ & & \\
\hline \multicolumn{2}{|c|}{ Total per 100,000 population Carlow/Kilkenny/South Tipperary } & 8.3 & 9.7 & 13.6 & & & & \\
\hline \multicolumn{9}{|c|}{ Donegal, Sligo, Leitrim, West Cavan } \\
\hline Donegal & Acute Psychiatric Unit, Carnamuggagh & 2 & 11 & 7 & -4 & $-36.4 \%$ & 38 & $513(125)$ \\
\hline Sligo/Leitrim & Ballytivnan Sligo/Leitrim Mental Health Services & 4 & 8 & 6 & -2 & $-25.0 \%$ & 52 & $527(132)$ \\
\hline \multicolumn{2}{|c|}{ Total Donegal, Sligo, Leitrim, West Cavan } & 6 & 19 & 13 & -6 & $-31.6 \%$ & & \\
\hline \multicolumn{2}{|c|}{ Total per 100,000 population Donegal, Sligo, Leitrim, West Cavan } & 2.5 & 8.0 & 5.5 & & & & \\
\hline \multicolumn{9}{|c|}{ Mid-West (Limerick, North Tipperary, Clare) } \\
\hline Clare & $\begin{array}{l}\text { Acute Psychiatric Unit, Midwestern Regional Hospital, } \\
\text { Ennis }\end{array}$ & 8 & 4 & 1 & -3 & $-75.0 \%$ & 39 & $412(123)$ \\
\hline Limerick & Acute Psychiatric Unit 5B, Midwestern Regional Hospital & 21 & 16 & 18 & 2 & $12.5 \%$ & 50 & $581(205)$ \\
\hline \multicolumn{2}{|c|}{ Total Limerick, North Tipperary, Clare/Mid-West } & 29 & 20 & 19 & -1 & $-5.0 \%$ & & \\
\hline \multicolumn{2}{|c|}{ Total per 100,000 population Limerick, North Tipperary, Clare/Mid-West } & 8.0 & 5.5 & 5.3 & & & & \\
\hline \multicolumn{9}{|c|}{ West (Galway, Mayo and Roscommon) } \\
\hline East Galway & St Brigid's Hospital, Ballinasloe & 47 & 38 & 23 & -15 & $-39.5 \%$ & 77 & $412(114)$ \\
\hline Mayo & Adult Mental Health Unit, Mayo General Hospital & 12 & 2 & 1 & -1 & $-50.0 \%$ & 32 & $473(222)$ \\
\hline West Galway & Psychiatric Unit, University College Hospital Galway & 22 & 21 & 15 & -6 & $-28.6 \%$ & 43 & $501(105)$ \\
\hline \multicolumn{2}{|c|}{ Total Galway, Mayo and Roscommon/West } & 81 & 61 & 39 & -22 & $-36.1 \%$ & & \\
\hline \multicolumn{2}{|c|}{ Total per 100,000 population Galway, Mayo and Roscommon/West } & 19.6 & 14.7 & 9.4 & & & & \\
\hline \multicolumn{9}{|c|}{ National Forensic Service } \\
\hline N/A & Central Mental Hospital $^{f}$ & - & 4 & 5 & 1 & $25.0 \%$ & 93 & $59(3)$ \\
\hline
\end{tabular}




\section{Table 5 continued}

\begin{tabular}{|c|c|c|c|c|c|c|c|c|}
\hline Catchment Area & Approved Centre Name & $\begin{array}{l}\text { Number of } \\
\text { Programmes } \\
\text { of ECT in } 2008 \\
\end{array}$ & $\begin{array}{c}\text { Number of } \\
\text { Programmes of } \\
\text { ECT in } 2009\end{array}$ & $\begin{array}{l}\text { Number of } \\
\text { Programmes of } \\
\text { ECT in } 2010\end{array}$ & Difference & $\begin{array}{c}\% \\
\text { Change }\end{array}$ & $\begin{array}{c}\text { Bed } \\
\text { numbers } \\
\text { in } 2010 \\
\end{array}$ & $\begin{array}{c}\text { Admissions in } \\
2010 \\
\end{array}$ \\
\hline \multicolumn{9}{|l|}{ Independents ${ }^{\mathrm{g}}$} \\
\hline $\mathrm{N} / \mathrm{A}$ & St John of God Hospital Limited & 21 & 24 & 15 & -9 & $-37.5 \%$ & 183 & $1,632(285)^{g}$ \\
\hline $\mathrm{N} / \mathrm{A}$ & St Patrick's University Hospital $^{\mathrm{h}}$ & 124 & 126 & 117 & -9 & $-7.1 \%$ & 238 & $2,852(1,189)$ \\
\hline Total Independents & & 145 & 150 & 132 & -18 & $-12.0 \%$ & & \\
\hline \multicolumn{2}{|c|}{ Total All Approved Centres } & 407 & 373 & 347 & -26 & $-7.0 \%$ & & \\
\hline
\end{tabular}

a Jonathan Swift Clinic referred patients to St Patrick's University Hospital for administration of ECT in 2008,2009 and 2010.

b Acute Psychiatric Unit, Cavan General Hospital 'Did Not Administer ECT in 2008 and the ECT suite was only operational in Q3 \& Q4 2009.

c St Vincent's Hospital, Fairview referred patients to the Mater Hospital for administration of ECT in 2008, 2009 and 2010.

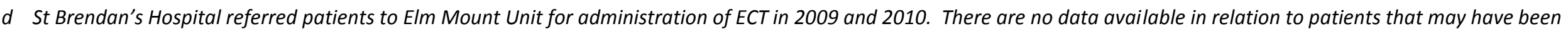
referred for treatment in 2008.

e St Stephen's Hospital and Carraig Mór Centre referred patients to South Lee Adult Mental Health Services for administration of ECT in 2010. There are no data available in relation to patients that may have been referred for treatment in 2008 and 2009.

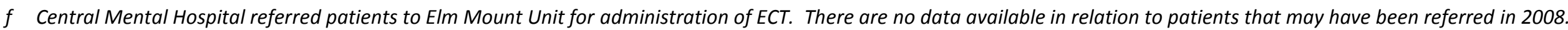

$g$ The number of admissions and depressed admissions for Cluain Mhuire has been included in the number of admissions and depressed admissions for St John of God Hospital Limited to enable a more accurate reflection of rate of ECT per admission/Depressive disorder admission

$h$ St Patrick's data for 2010 includes 16 programmes of ECT administered to patients referred from St Edmundsbury Hospital. There are no data available in relation to patients that may have been referred 2008 and 2009. The number of admissions and depressed admissions for St Edmundsbury Hospital has been included in the number of admissions and depressed admissions for St Patrick's Hospital to enable a more accurate reflection of rate of ECT per admission/ Depressive disorder admission.

Notes Bed Numbers in 2010 were sourced from the Inspector of Mental Health Services Approved Centre Inspection Reports 2010

Admissions in 2010 were sourced from the Health Research Board's Statistics Series 15 Activities of Irish Psychiatric Units and Hospitals 2010 . (These figures only include admissions to approved centres in 2010 and do not account for any residents who were admitted prior to 2010.)

Rates per 100,000 population were calculated by multiplying the number of programmes of ECT by 100,000 and dividing by the catchment population. (See Appendix 3 for catchment population figures). For the purpose of this report the population used for Dun Laoghaire, Dublin South-East \& Wicklow is 199,775 (total population 372,107- Cluain Mhuire population 172,332). Rates are not calculated for the Central Mental Hospital or the Independent Sector as they accept admissions on a national basis. 


\section{ECT Data by Quarter}

Figure 1 shows that the highest number of programmes ${ }^{14}$ of ECT $(n=93)$ were administered in Quarter 1 and the lowest number in Quarter $3(n=75)$. As the number of programmes of ECT is greater than the number of residents ${ }^{15}$, we can infer that one or more residents received more than one programme of ECT in each quarter. The mean number of treatments per programme ranged from 6.4 to 7.1 treatments per programme over the four quarters of 2010.

Figure 1: Administration of ECT. Number of Treatments, Programmes and Residents by Quarter in 2010.

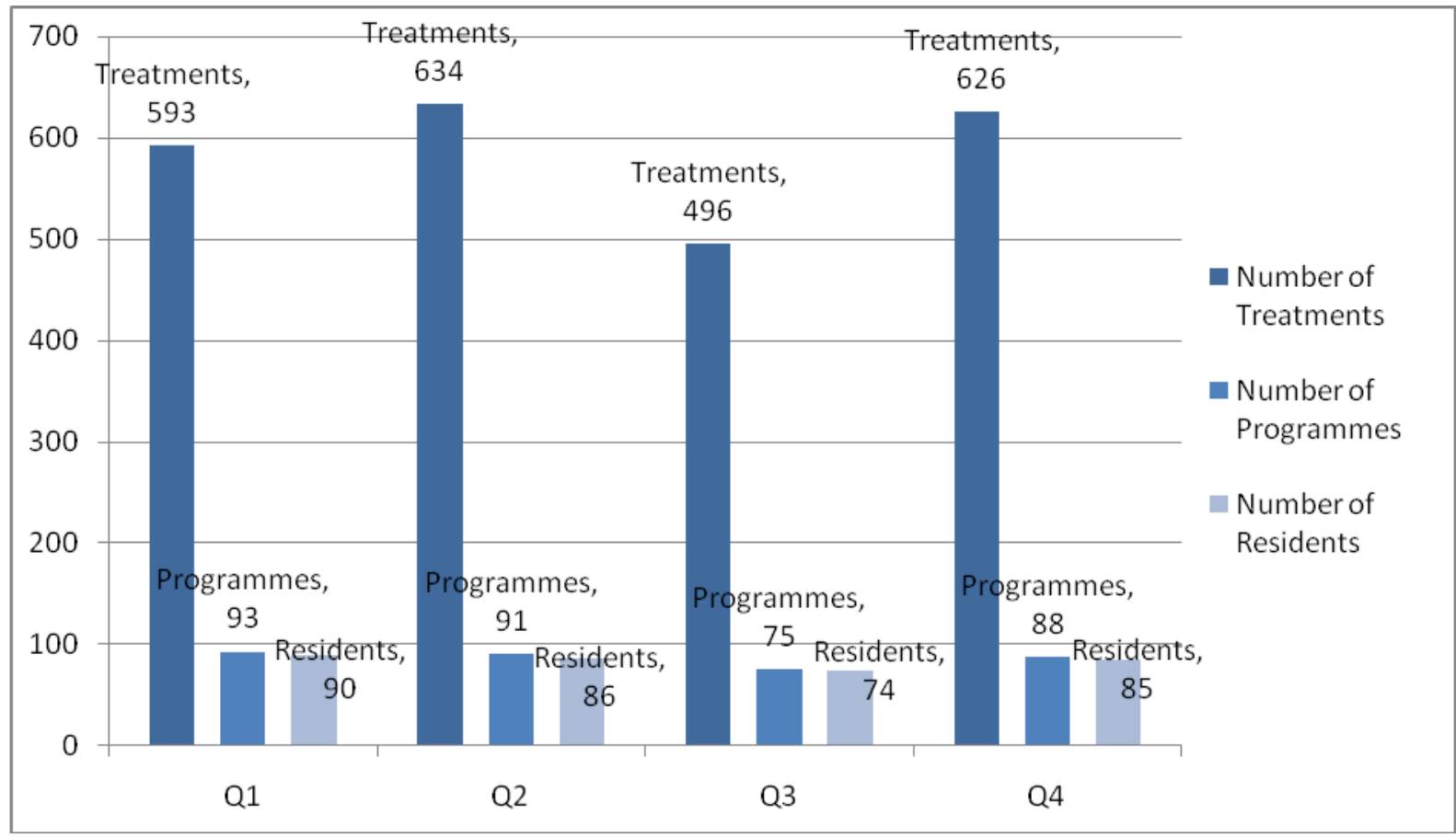

\footnotetext{
${ }^{14}$ Programme of ECT refers to no more than 12 treatments prescribed by a consultant psychiatrist.

${ }^{15}$ Resident: means a person receiving care and treatment in a centre.
} 


\section{Legal Status}

Figure 2 shows that in 2010, the majority of residents that were administered ECT were voluntary patients, at the time when the ECT Register was being completed. The proportion of residents administered ECT who were voluntary was at least $80 \%$ in all quarters. This is in keeping with what was reported in 2008 and 2009.

Figure 2: Legal Status of Residents that were administered ECT in 2008, 2009 and 2010 percentage of residents by Quarter.

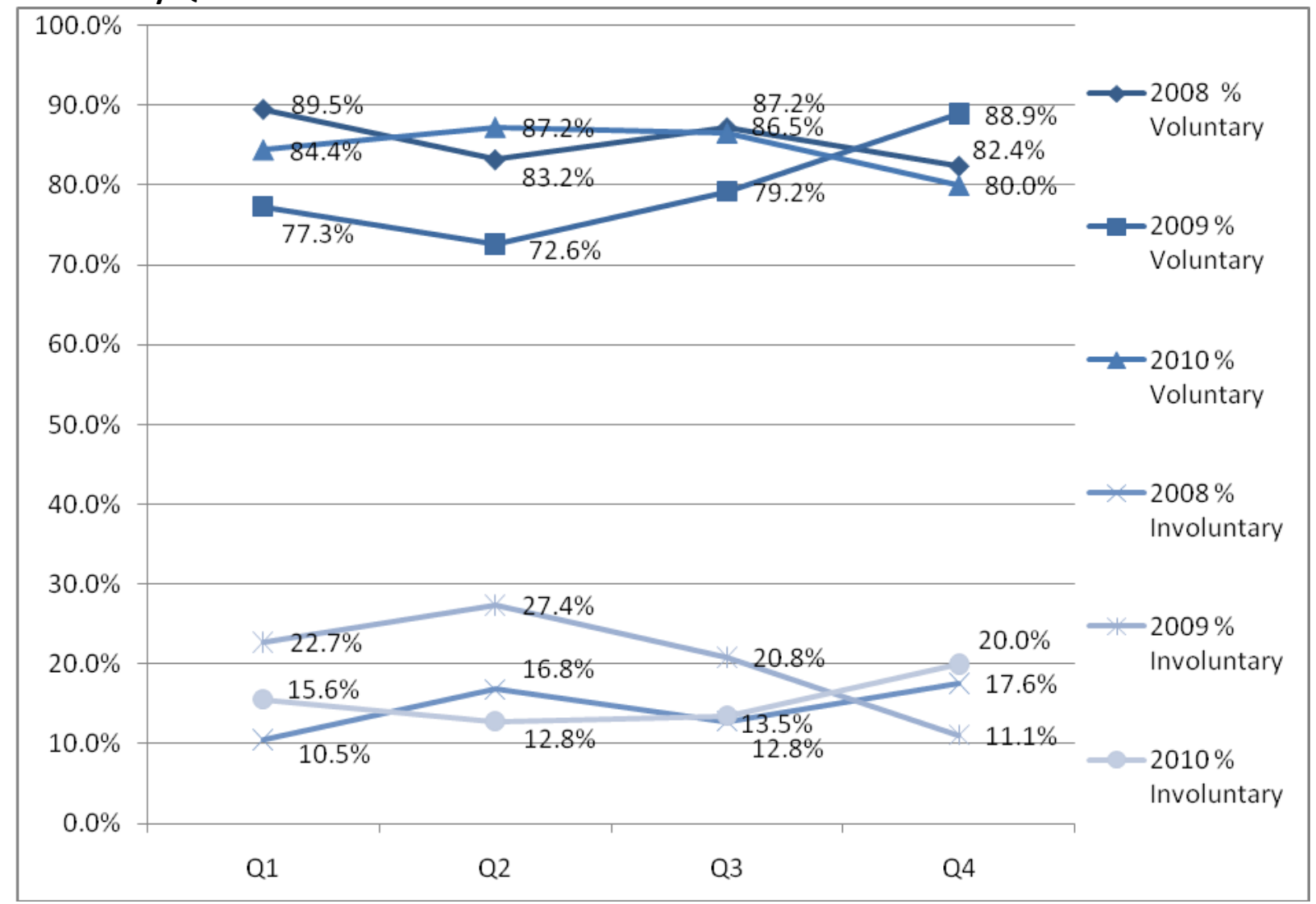

In 2010, the ECT Register and ECT data collection template were updated to capture information regarding a patient's change in legal status. Two approved centres indicated that they had one programme each where a patient's legal status changed during the programme of ECT. In both cases, the patient's legal status changed from involuntary to voluntary during their programme of ECT. 


\section{Diagnosis}

Depressive disorders were indicated for $84.3 \%\left(257 / 305^{16}\right)$ of all programmes of ECT administered in 2010. Schizophrenia was the next most common diganosis associated with ECT adminsitration as it accounted for $8.2 \%$ (25/305) of all programmes followed by a diagnosis of Mania which accounted for $3.9 \%(12 / 305)$ of programmes. These findings are similar to what was indicated in 2008 and 2009.

Figure 3: Diagnosis, percentage of programmes in 2010.

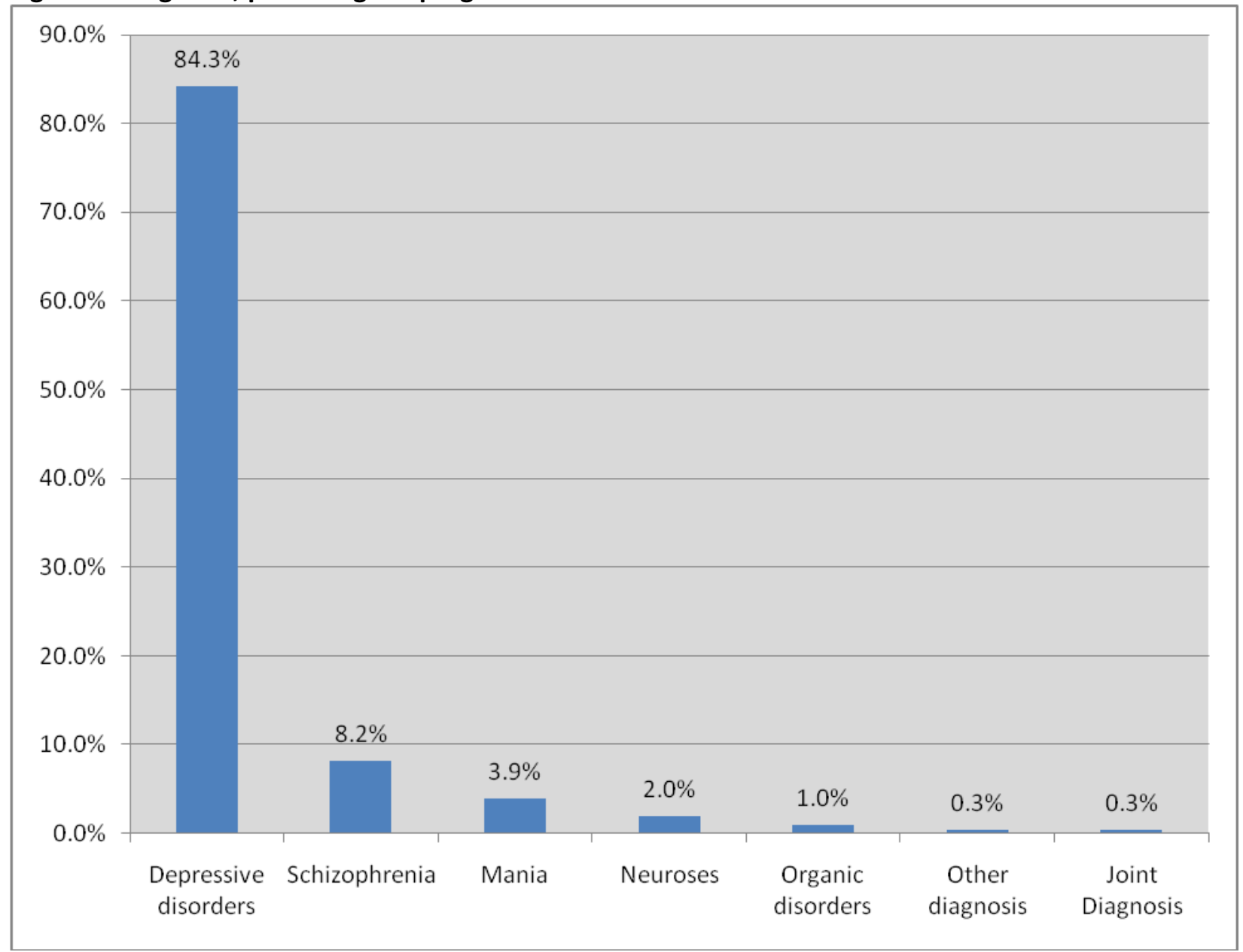

See Appendix 4 for details regarding the ICD 10 Codes and Diagnostic Groups used in this report.

\footnotetext{
${ }^{16}$ Diagnosis was not available in relation to 42 programmes of ECT.
} 


\section{Indications for ECT}

In 2010, refractory to medication was reported as the most prevelant indication for ECT and accounted for over half $59.8 \%\left(195 / 326^{17}\right)$ of all programmes of ECT as can be seen in Figure 4. The second most popular indication was multiple indications which accounted for $17.5 \%$ (57/326) of ECT programmes, followed by rapid response required which was noted for $14.7 \%$ (48/326) of progarmmes. These findings are relatively unchanged on what was reported in 2008 and 2009.

Figure 4: Indications for ECT, percentage of programmes in 2010.

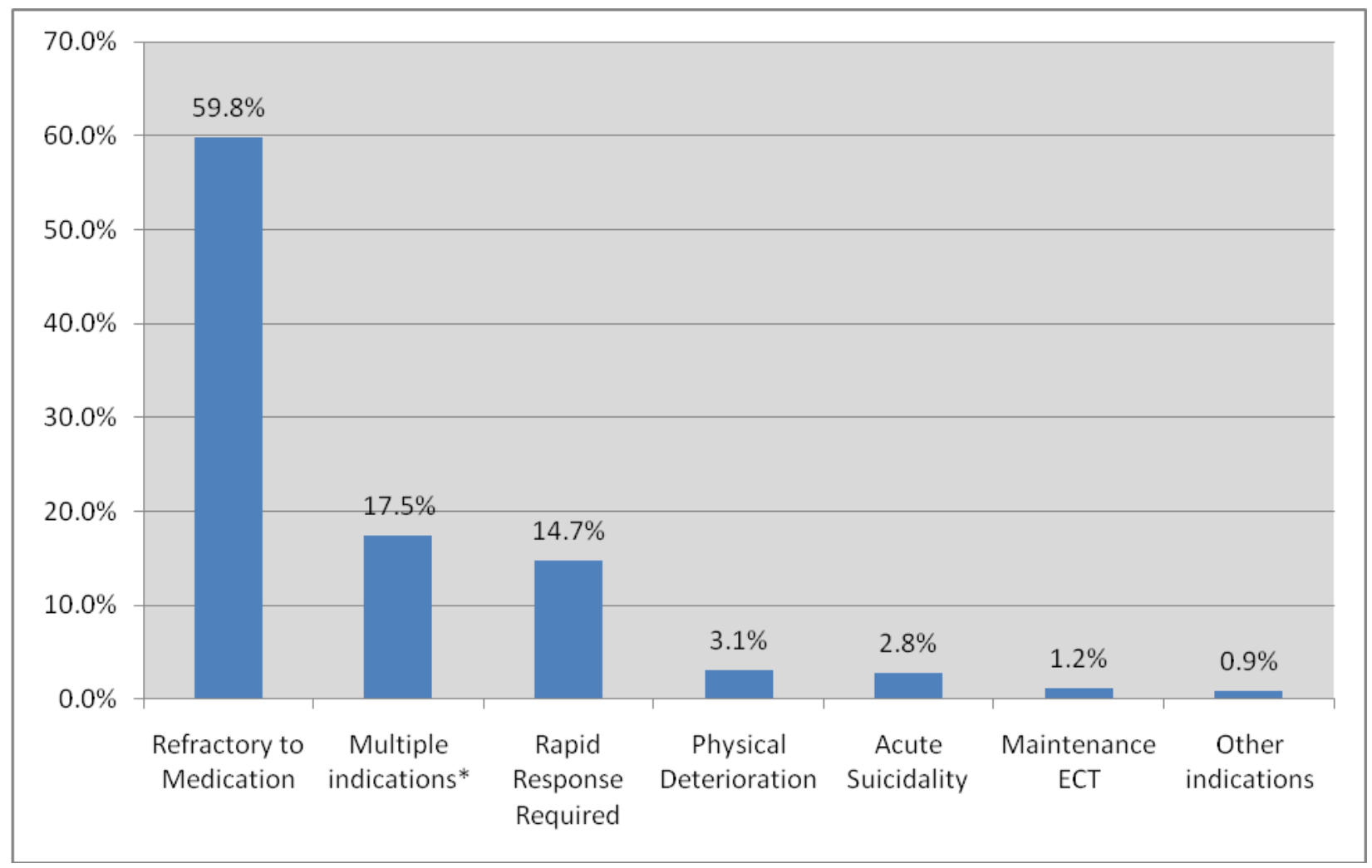

* Multiple indications means a combination of two or more of the following: acute suicidality, maintenance ECT, physical deterioration, rapid response required and refractory to medication.

${ }^{17}$ Indication for ECT was not available in relation to 21 programmes of ECT. 


\section{Reason for termination of ECT}

Figure 5 shows that improvement was indicated (on the ECT Register by the consultant psychiatrist responsible for the care and treatment of the resident) as the reason for the termination of $86.8 \%$ of ECT $\left(296 / 341^{18}\right)$ programmes in 2010 . The next most common reason for terminating a programme of ECT was that the patient withdrew his or her consent which was reported as the reason for termination of ECT for $5.0 \%(17 / 341)$ of programmes.

Figure 5: Reason for termination of ECT, percentage of programmes in 2010

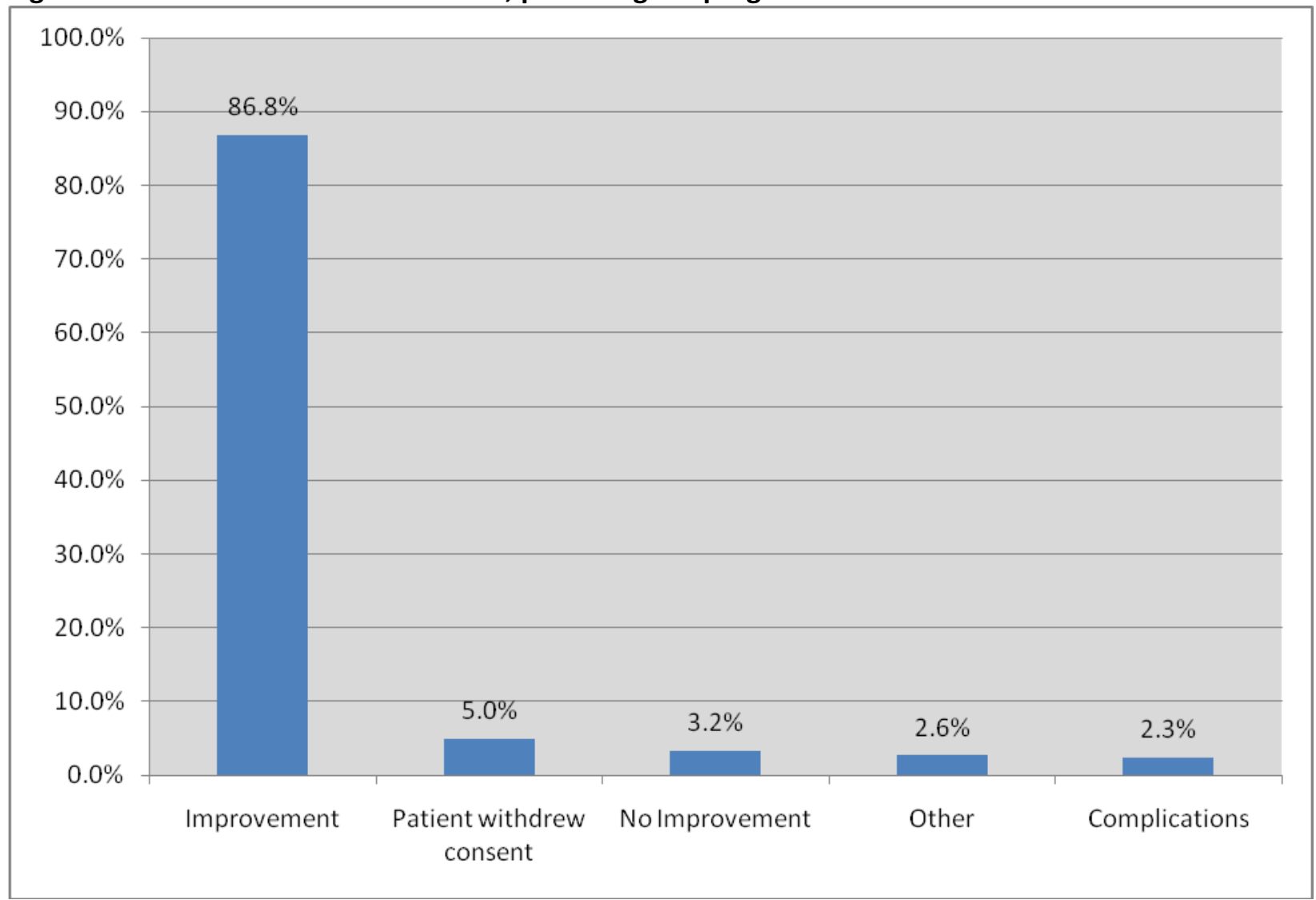

${ }^{18}$ Reason for termination of ECT was not available in relation to six programmes of ECT. 


\section{Outcome at termination of ECT}

Figure 6 shows that $94.7 \%$ of all programmes $\left(322 / 340^{19}\right)$ of ECT in 2010 were reported to have varying levels of improvement as their treatment outcome (as recorded on the ECT Register by the consultant psychiatrist responsible for the care and treatment of the resident). This is relatively unchanged from what was reported in 2009, when $93.9 \%$ were reported to have varying levels of improvement.

The most common outcome reported at the termination of a programme of ECT was that "significant improvement" had occurred for the patient. For 31.2\% (106/340) of programmes, the outcome recorded was "complete recovery". Just over $5 \%$ of programmes had an outcome of no change or deterioration.

\section{Figure 6: Outcome at termination of ECT, percentage of programmes in 2010.}

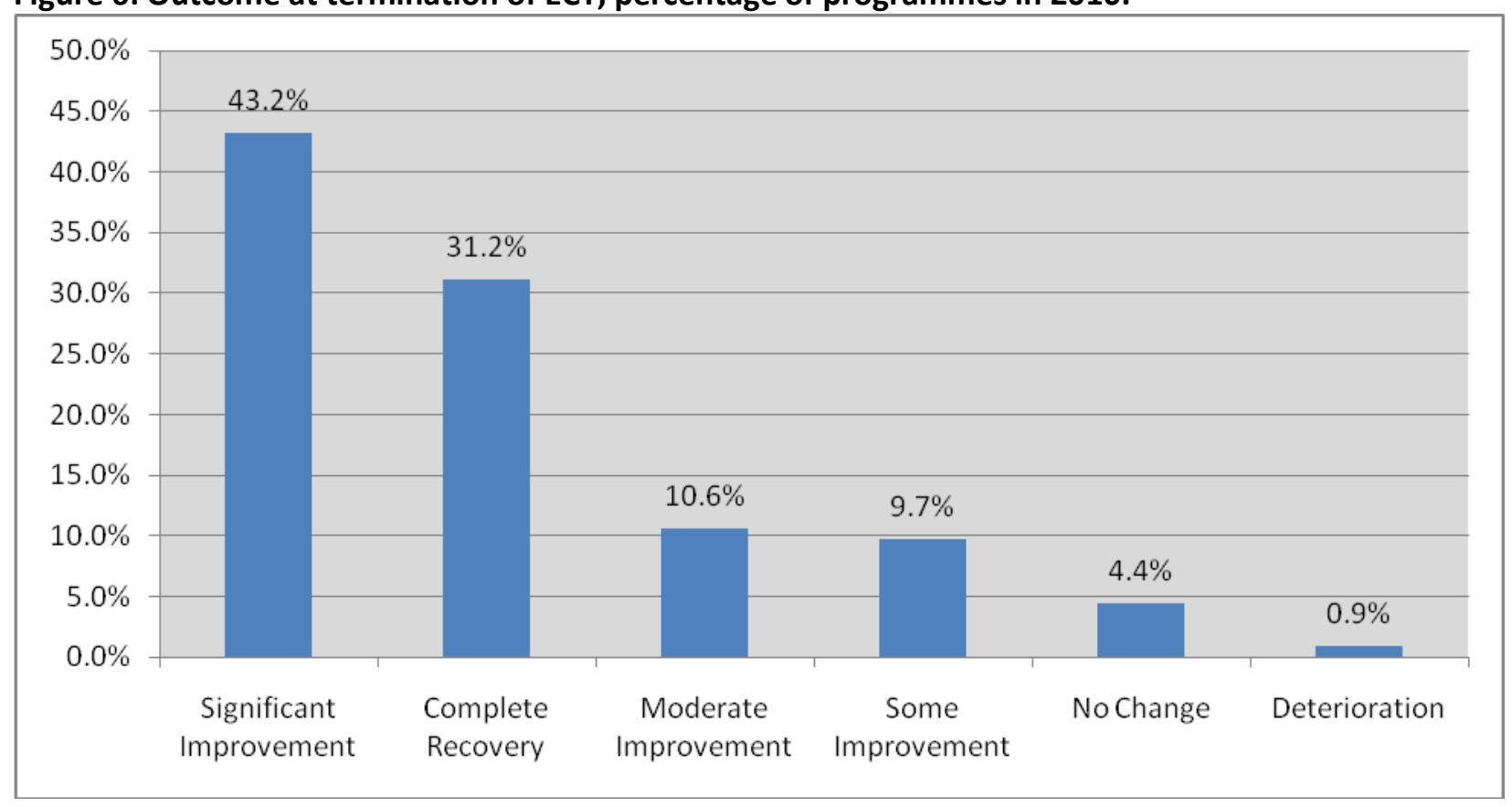

${ }^{19}$ Outcome at termination of ECT was not available in relation to seven programmes of ECT. 


\subsection{Administration of ECT without consent}

\section{Form 16 Treatment without consent Electroconvulsive Therapy Involuntary Patient (Adult)}

Where a patient is unable to give consent or is unwilling to give consent, Section 59 (1)(b) of the Mental Health Act 2001 applies

59.-(1) A programme of electro-convulsive therapy shall not be administered to a patient unless either-

(a) the patient gives his or her consent in writing to the administration of the programme of therapy, or

(b) where the patient is unable or unwilling to give such consent -

(i) The programme of therapy is approved (in a form specified by the Commission) by the consultant psychiatrist responsible for the care and treatment of the patient, and

(ii) The programme of therapy is also authorised (in a form specified by the Commission) by another consultant psychiatrist following referral of the matter to him or her by the first mentioned psychiatrist.

(2) The Commission shall make rules providing for the use of electro-convulsive therapy and a programme of electro-convulsive therapy shall not be administered to a patient except in accordance with such rules.

The Rules specify that Form 16: Treatment Without Consent Electroconvulsive Therapy Involuntary Patient (Adult) must be completed by both consultant psychiatrists and placed in the patient's clinical file. A copy must also be sent to the Mental Health Commission.

Based on the data that were returned to the Commission, 35 out of 347 programmes of ECT (10.1\%) were administered to involuntary patients who were either unable or unwilling to give consent in 2010 . This represents a decrease in the percentage of programmes of ECT administered without consent that were reported in 2009 (11.8\%) and 2008 (12\%).

Forty Form $16 \mathrm{~s}$ were received by the Commission in 2010. After data validation, it was confirmed that the administration of ECT without consent did not proceed in five of these cases. The data below relate to the 35 forms where ECT without consent was administered in 2010.

The 35 forms returned were in relation to 32 individual patients, two of whom were administered more than one programme of ECT without consent.

Of those were administered ECT without consent, a higher proportion were females (65.6\%) than male (34.4\%). This is similar to the gender breakdown in relation to all programmes of ECT in 2010. The majority of patients (59.4\%) were between 18 and 64 years of age and $40.6 \%$ were 65 years of age or older. This represents a slight increase in the number of patients in the 18 to 64 years of age category from previous years when just over half of patients fell into this age group.

Less than three in every ten (20/67) approved centres reported administration of ECT without consent to the Commission in 2010 (Table 4). Due to the small numbers and sensitive nature of the information, the number of forms returned by each centre is not provided. 
Table 6: Approved Centres that reported administration of ECT without consent in 2010.

\begin{tabular}{|l|l|}
\hline Catchment Area & Approved Centre Name \\
\hline Dun Laoghaire, Dublin South-East \& Wicklow \\
\hline Dublin South East & Elm Mount Unit, St Vincent's University Hos \\
\hline \multicolumn{2}{|l}{} \\
\hline Dublin West/Dublin South West \& Dublin South City \\
\hline Dublin South City & Jonathan Swift Clinic, St James's Hospital \\
\hline Dublin South West & Acute Psychiatric Unit, AMNCH, Tallaght \\
\hline
\end{tabular}

\begin{tabular}{|l|l|}
\hline \multicolumn{2}{|l|}{ Kildare/West Wicklow, Laois/Offaly \& Longford/Westmeath } \\
\hline Kildare/West Wicklow & Lakeview Unit, Naas General Hospital \\
\hline Longford/Westmeath & St Loman's Hospital, Mullingar \\
\hline
\end{tabular}

Dublin North Central/North West Dublin

\begin{tabular}{|l|l}
\hline Dublin North Central & St Vincent's Hospital $^{\text {b }}$ \\
\hline Dublin North West & St Brendan's Hospital $^{\text {b }}$
\end{tabular}

\begin{tabular}{|c|c|}
\hline \multicolumn{2}{|l|}{ North Lee/North Cork } \\
\hline North Cork & St Stephen's Hospital ${ }^{b}$ \\
\hline North Lee & Carraig Mór Centre $^{\mathrm{b}}$ \\
\hline \multicolumn{2}{|l|}{ South Lee/West Cork/Kerry } \\
\hline South Lee & South Lee Mental Health Unit, Cork University Hospital \\
\hline Kerry & Acute Mental Health Admission Unit, Kerry General Hospital \\
\hline \multicolumn{2}{|l|}{ Waterford/Wexford } \\
\hline Wexford & St Senan's Hospital \\
\hline \multicolumn{2}{|c|}{ Carlow/Kilkenny/South Tipperary } \\
\hline Carlow/Kilkenny & Department of Psychiatry, St Luke's Hospital, Kilkenny \\
\hline \multicolumn{2}{|c|}{ Donegal, Sligo, Leitrim, West Cavan } \\
\hline Donegal & Acute Psychiatric Unit, Carnamuggagh, Letterkenny \\
\hline \multicolumn{2}{|c|}{ West (Galway, Mayo and Roscommon) } \\
\hline East Galway & St Brigid's Hospital, Ballinasloe \\
\hline Mayo & Adult Mental Health Unit, Mayo General Hospital \\
\hline West Galway & Department of Psychiatry, University College Hospital Galway \\
\hline \multicolumn{2}{|l|}{ National Forensic Service } \\
\hline National Forensic Service & Central Mental Hospital $^{\mathrm{b}}$ \\
\hline \multicolumn{2}{|c|}{ Independent Service Providers } \\
\hline N/A & St John of God Hospital \\
\hline $\mathrm{N} / \mathrm{A}$ & St Patrick's Hospital \\
\hline
\end{tabular}

a Jonathan Swift Clinic, St James's Hospital referred patient(s) to another approved centre for ECT treatment, they made their own data return in relation to the programmes of ECT that were administered to their patients in 2010

b St Vincent's Hospital, St Brendan's Hospital, St Stephen's Hospital, Carraig Mór Centre and Central Mental Hospital referred patient(s) to other approved centres for the administration of ECT. The approved centres which administered ECT included these programmes of ECT in their 2010 data returns. 
As required by $\mathrm{S} 59$ of the Mental Health Act 2001 the consultant psychiatrist responsible for the care and treatment of the patient ('treating consultant psychiatrist'), must approve the programme of ECT without consent and it must be authorised by 'another consultant psychiatrist' following referral of the matter to him or her by the first mentioned psychiatrist. Form 16 requires that each consultant psychiatrist must indicate whether, in their clinical judgement, the patient is unable or unwilling to give consent. Table 5 gives a breakdown of what was indicated by each consultant psychiatrist on the Form 16 s sent to the Commission in 2010. On the majority (67.5\%) of all forms received in 2010 , both consultant psychiatrists indicated that the patient was unable to give consent.

Table 7: Patient unable or unwilling to give consent. Number and percentage of Form 16s returned to the Commission in 2010.

\begin{tabular}{|c|c|c|c|c|c|c|}
\hline \multirow[b]{2}{*}{ Unable or unwilling to give consent } & \multicolumn{2}{|c|}{$\begin{array}{l}\text { Administration of ECT } \\
\text { without consent } \\
\text { did proceed }\end{array}$} & \multicolumn{2}{|c|}{$\begin{array}{l}\text { Administration of ECT } \\
\text { without consent } \\
\text { did not proceed }\end{array}$} & \multicolumn{2}{|c|}{$\begin{array}{l}\text { All Form 16s } \\
\text { returned in } 2010\end{array}$} \\
\hline & $\begin{array}{l}\text { Number of } \\
\text { Forms }\end{array}$ & $\begin{array}{c}\% \text { of } \\
\text { Forms }\end{array}$ & $\begin{array}{l}\text { Number } \\
\text { of Forms }\end{array}$ & $\%$ of Forms & $\begin{array}{l}\text { Number } \\
\text { of forms }\end{array}$ & $\begin{array}{c}\% \text { of } \\
\text { Forms }\end{array}$ \\
\hline $\begin{array}{l}\text { Both consultant psychiatrists indicated the } \\
\text { patient was unable }\end{array}$ & 23 & $65.7 \%$ & 4 & $80.0 \%$ & 27 & $67.5 \%$ \\
\hline $\begin{array}{l}\text { Both consultant psychiatrists indicated the } \\
\text { patient was unwilling }\end{array}$ & 5 & $14.2 \%$ & 0 & $0.0 \%$ & 5 & $12.5 \%$ \\
\hline $\begin{array}{l}\text { Both consultant psychiatrists ticked unwilling } \\
\text { and unable }\end{array}$ & 1 & $2.9 \%$ & 1 & $20.0 \%$ & 2 & $5.0 \%$ \\
\hline $\begin{array}{l}\text { Treating consultant psychiatrist indicated the } \\
\text { patient was unable and Another consultant } \\
\text { psychiatrist indicated the patient was } \\
\text { unwilling }\end{array}$ & 1 & $2.9 \%$ & 0 & $0.0 \%$ & 1 & $2.5 \%$ \\
\hline $\begin{array}{l}\text { Treating consultant psychiatrist indicated the } \\
\text { patient was unwilling and Another consultant } \\
\text { psychiatrist indicated the patient was unable }\end{array}$ & 2 & $5.7 \%$ & 0 & $0.0 \%$ & 2 & $5.0 \%$ \\
\hline $\begin{array}{l}\text { Treating consultant psychiatrist ticked both } \\
\text { and Another consultant psychiatrist indicated } \\
\text { unable }\end{array}$ & 2 & $5.7 \%$ & 0 & $0.0 \%$ & 2 & $5.0 \%$ \\
\hline $\begin{array}{l}\text { Treating consultant psychiatrist ticked both } \\
\text { and Another consultant psychiatrist indicated } \\
\text { unwilling }\end{array}$ & 1 & $2.9 \%$ & 0 & $0.0 \%$ & 1 & $2.5 \%$ \\
\hline Total & 35 & $100.0 \%$ & 5 & $100.0 \%$ & 40 & $100.0 \%$ \\
\hline
\end{tabular}




\section{Conclusion}

This report has described activity in relation to the administration of ECT in approved centres during 2010. The quarterly data show that there were 347 programmes of ECT administered to inpatients in approved centres in 2010; this represents a 7\% decrease on the number of programmes reported in 2009.

As in previous years, in 2010, the majority of programmes of ECT were administered to patients who were capable of giving consent. Most programmes of ECT were administered to females and the most frequent diagnosis indicated was Depressive disorders. This is reflective of a greater proportion of women (57.8\%) admitted to approved centres with a primary diagnosis of depressive disorders in 2010. A smaller proportion (42.2\%) of men were admitted with such a primary diagnosis ${ }^{20}$. Overall, the use of ECT in Ireland, in 2010, is in line with what has been reported in Scotland for the same period.

There are currently no national clinical guidelines for ECT in Ireland however, guidelines produced by NICE ${ }^{21}$ recommend that ECT is used only to achieve rapid and short-term improvement of severe symptoms after an adequate trial of other treatment options has proven ineffective and/or when the condition is considered to be potentially life-threatening, in individuals with: severe depressive illness; catatonia; a prolonged or severe manic episode.

Ideally these data would be collected at an individual level which could facilitate evaluation of not only service capacity and utilisation but also understanding, measuring and evaluating treatment outcomes and ensuring the highest standard of patient care. We will continue to work with services to enhance the quality of the data and usefulness of these reports and are we are committed to carrying out more indepth research on the use of ECT in Ireland under the Mental Health Commission and Department of Psychiatry, Royal College of Surgeons in Ireland MD/ PhD programme, which commenced in 2011.

The Commission would like to thank all those involved in returning the information requested which has enabled this report to be completed.

\footnotetext{
${ }^{20}$ Daly A, Walsh D (2011), HRB Statistics Series 15 Activities of Irish Psychiatric Units and Hospitals 2010. (Dublin: HRB).

${ }^{21}$ National Institute for Clinical Excellence (2003). Guidance on the Use of Electroconvulsive Therapy (Technology Appraisal 59). (NICE).
} 


\section{Appendix 1 - ECT Data collection templates used in 2010}

\begin{tabular}{|c|c|c|c|c|c|c|}
\hline & \multicolumn{6}{|c|}{$\begin{array}{l}\text { Section 59(2) Rules and Section 33(3)(e)Code of Practice on the Use of Electro-conv } \\
\text { Therapy Report on the Use of Electro-convulsive Therapy } \\
\text { Information should be sourced directly from the ECT Register. Please read the acco } \\
\text { completing the template. }\end{array}$} \\
\hline 1. & Quarter: & Year: & & & & \\
\hline \multirow[t]{3}{*}{2.} & \multicolumn{6}{|l|}{ (a) Approved Centre Name } \\
\hline & \multicolumn{6}{|l|}{ (b) Referring Approved Centre Name (if applicable) } \\
\hline & & & & & & Total \\
\hline \multirow[t]{2}{*}{3.} & \multicolumn{5}{|l|}{ Number of Programmes of ECT administered } & \\
\hline & & & Involuntary & Voluntary & WOC & Total \\
\hline \multirow[t]{3}{*}{4.} & a. Number of Residents that were administered $\mathrm{E}$ & & & & & \\
\hline & \multicolumn{6}{|c|}{ b. If any patient's legal status changed during the programme of ECT please give details below } \\
\hline & & & Female & \multicolumn{2}{|c|}{ Male } & Total \\
\hline 5. & \multicolumn{2}{|l|}{ Gender (breakdown of residents) } & & & & \\
\hline 6. & \multicolumn{5}{|l|}{ Primary ICD 10 Diagnosis } & \\
\hline 7. & \multicolumn{5}{|l|}{ Indications for ECT } & \\
\hline \multirow[t]{7}{*}{ a. } & \multicolumn{5}{|l|}{ One Indication for a Single Programme of ECT } & \\
\hline & \multicolumn{5}{|l|}{ Rapid Response Required } & \\
\hline & \multicolumn{5}{|l|}{ Acute Suicidality } & \\
\hline & \multicolumn{5}{|l|}{ Physical Deterioration } & \\
\hline & \multicolumn{5}{|l|}{ Refractory to Medication } & \\
\hline & \multicolumn{5}{|l|}{ Maintenance ECT } & \\
\hline & \multicolumn{5}{|c|}{ Other (please specify if information provided on the ECT Register) } & \\
\hline b. & \multicolumn{5}{|c|}{$\begin{array}{l}\text { Multiple Indications for a Single programme of ECT (if there were multiple indications ticked on the ECT } \\
\text { Register for a single programme of ECT please specify the combination below) }\end{array}$} & \\
\hline 8. & \multicolumn{5}{|l|}{ Total Number of Treatments Administered } & \\
\hline \multirow[t]{6}{*}{9.} & \multicolumn{5}{|l|}{ Reason for Termination of Treatment } & \\
\hline & \multicolumn{5}{|l|}{ Improvement } & \\
\hline & \multicolumn{5}{|l|}{ No Improvement } & \\
\hline & \multicolumn{5}{|l|}{ Patient Withdrew Consent } & \\
\hline & Complications & & & & & \\
\hline & Other & & & & & \\
\hline 10. & Outcome at termination of ECT & & & & & \\
\hline & Complete Recovery & & & & & \\
\hline & Significant Improvement & & & & & \\
\hline & Moderate Improvement & & & & & \\
\hline & Some Improvement & & & & & \\
\hline & No Change & & & & & \\
\hline & Deterioration & & & & & \\
\hline 11. & Report Completed by: & & & & & \\
\hline & Job title: & & Date (c & nm/yyyy): & & \\
\hline
\end{tabular}




\section{Administration of ECT to individual patients}

\section{Guidance:}

Approved centres that have administered ECT to one or more patients in a calendar year are required to report on the number of individuals that were administered ECT in their approved centre.

A programme of ECT refers to no more than 12 treatments of ECT prescribed by a consultant psychiatrist and each programme should be recorded as one entry in the ECT Register.

Please include all residents of the approved centre that were administered ECT and individuals that were referred from another centre for administration of ECT.

This information should be returned at the same time as Quarter 4 ECT data returns

\begin{tabular}{|c|c|c|c|c|}
\hline Approved Centre Name: & & & & \\
\hline \multicolumn{5}{|l|}{ Year: } \\
\hline Patient First Name & Patient Surname & Date of Birth & Gender & Number of programmes of ECT \\
\hline & & & & \\
\hline & & & & \\
\hline & & & & \\
\hline & & & & \\
\hline & & & & \\
\hline & & & & \\
\hline & & & & \\
\hline & & & & \\
\hline & & & & \\
\hline & & & & \\
\hline & & & & \\
\hline & & & & \\
\hline & & & & \\
\hline & & & & \\
\hline & & & & \\
\hline & & & & \\
\hline & & & & \\
\hline & & & & \\
\hline & & & & \\
\hline & & & & \\
\hline & & & & \\
\hline & & & & \\
\hline & & & & \\
\hline & & & & \\
\hline & & & & \\
\hline & & & & \\
\hline & & & & \\
\hline & & & & \\
\hline & & & & \\
\hline 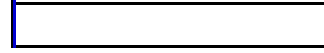 & & & & \\
\hline
\end{tabular}




\section{Appendix 2 - Overview of 2008, 2009 and 2010 Data Returns}

Table A1: Type of ECT data return by Approved Centres in 2008, 2009 and 2010

\begin{tabular}{|c|c|c|c|c|}
\hline Catchment Area & Approved Centre Name & 2008 Data Type & 2009 Data Type & 2010 Data Type \\
\hline \multicolumn{5}{|c|}{ Dun Laoghaire, Dublin South-East \& Wicklow } \\
\hline Dublin South East & Elm Mount Unit, St Vincent's University Hospital & $\sqrt{ }$ & $\sqrt{ }$ & $\sqrt{ }$ \\
\hline East Wicklow & Newcastle Hospital & $\sqrt{ }$ & $\sqrt{ }$ & $\sqrt{ }$ \\
\hline \multicolumn{5}{|c|}{ Dublin West/Dublin South West \& Dublin South City } \\
\hline Dublin South City & Jonathan Swift Clinic & $\sqrt{*}$ & $\sqrt{*}$ & $\sqrt{*}$ \\
\hline Dublin South West & Acute Psychiatric Unit AMNCH & $\sqrt{ }$ & $\sqrt{ }$ & $\sqrt{ }$ \\
\hline Dublin South West & St Loman's Hospital, Palmerstown & DNA & DNA & DNA \\
\hline
\end{tabular}

\begin{tabular}{|c|c|c|c|c|}
\hline \multicolumn{4}{|c|}{ Kildare/West Wicklow, Laois/Offaly \& Longford/Westmeath } & \multirow[b]{2}{*}{$\sqrt{ }$} \\
\hline Kildare West/Wicklow & Lakeview Unit, Naas General Hospital & $\sqrt{ }$ & $\sqrt{ }$ & \\
\hline Laois/Offaly & $\begin{array}{l}\text { Department of Psychiatry, Midland Regional } \\
\text { Hospital, Portlaoise }\end{array}$ & $\sqrt{ }$ & $\sqrt{ }$ & $\sqrt{ }$ \\
\hline Laois/Offaly & St Fintan's Hospital & DNA & DNA & DNA \\
\hline Longford/Westmeath & St Loman's Hospital, Mullingar & $\sqrt{ }$ & $\sqrt{ }$ & $\sqrt{ }$ \\
\hline \multicolumn{4}{|c|}{ Cavan/Monaghan, Louth Meath } & \\
\hline Cavan/Monaghan & Acute Psychiatric Unit, Cavan General Hospital & DNA & $\sqrt{ } *$ & $\sqrt{ }$ \\
\hline Cavan/Monaghan & St Davnet's Hospital - Wards 4, 8 and 15 & NR & DNA & DNA \\
\hline Louth/Meath & Department of Psychiatry, Our Lady's Hospital, Navan & NR & NR & DNA \\
\hline Louth/Meath & St Brigid's Hospital, Ardee & NR & NR & DNA \\
\hline \multicolumn{4}{|c|}{ *ECT suite in Acute Psychiatric Unit, Cavan was only operational in Q3 \& Q4 2009} & \\
\hline \multicolumn{4}{|l|}{ Dublin North } & \\
\hline Dublin North & St Ita's Hospital - Mental Health Services & DNA & DNA & DNA \\
\hline \multicolumn{4}{|c|}{ Dublin North Central/North West Dublin } & \\
\hline $\begin{array}{l}\text { Dublin North } \\
\text { Central }\end{array}$ & St Aloysius Ward, Mater Misericordiae Hospital & $\sqrt{ }$ & $\sqrt{ }$ & $\sqrt{ }$ \\
\hline $\begin{array}{l}\text { Dublin North } \\
\text { Central }\end{array}$ & St Vincent's Hospital & Ref $O / A C$ & Ref O/AC & Ref O/AC \\
\hline Dublin North West & St Brendan's Hospital & DNA & Ref O/AC & Ref O/AC \\
\hline Dublin North West & Department of Psychiatry, Connolly Hospital & DNA & DNA & DNA \\
\hline Dublin North West & Sycamore Unit, Connolly Hospital & DNA & DNA & DNA \\
\hline \multicolumn{4}{|l|}{ North Lee/North Cork } & \\
\hline North Cork & St Stephen's Hospital & DNA & DNA & Ref $O / A C$ \\
\hline North Lee & Carraig Mór Centre & DNA & DNA & Ref $O / A C$ \\
\hline North Lee & St Michael's Unit, Mercy Hospital & $\sqrt{ }$ & NR & NR \\
\hline
\end{tabular}




\section{Table A1 continued}

\begin{tabular}{|c|c|c|c|c|}
\hline Catchment Area & Approved Centre Name & 2008 Data Type & 2009 Data Type & 2010 Data Type \\
\hline \multicolumn{5}{|c|}{ South Lee/West Cork/Kerry } \\
\hline Kerry & $\begin{array}{l}\text { Acute Mental Health Admission Unit, Kerry General } \\
\text { Hospital }\end{array}$ & $\sqrt{ }$ & $\sqrt{ }$ & $\sqrt{ }$ \\
\hline Kerry & St Finan's Hospital & DNA & DNA & DNA \\
\hline South Lee & South Lee Mental Health Unit, Cork University Hospital & NR & $\sqrt{ }$ & $\sqrt{ }$ \\
\hline South Lee & St Finbarr's Hospital & NR & DNA & DNA \\
\hline West Cork & $\begin{array}{l}\text { Centre for Mental Health Care and Recovery, Bantry } \\
\text { General Hospital }\end{array}$ & DNA & DNA & DNA \\
\hline \multicolumn{5}{|l|}{ Waterford/Wexford } \\
\hline Waterford & Department of Psychiatry, Waterford Regional Hospital & $\sqrt{ }$ & $\sqrt{ }$ & $\sqrt{ }$ \\
\hline Waterford & St Otteran's Hospital & NR & NR & DNA \\
\hline Wexford & St Senan's Hospital & $\sqrt{ }$ & $\sqrt{ }$ & $\sqrt{ }$ \\
\hline \multicolumn{5}{|c|}{ Carlow/Kilkenny/South Tipperary } \\
\hline Carlow/Kilkenny & Department of Psychiatry, St Luke's Hospital, Kilkenny & $\sqrt{ }$ & $\sqrt{ }$ & $\sqrt{ }$ \\
\hline Carlow/Kilkenny & St Canice's Hospital & DNA & DNA & DNA \\
\hline Carlow/Kilkenny & St Dympna's Hospital & DNA & DNA & DNA \\
\hline South Tipperary & St Luke's Hospital, Clonmel & NR & DNA & DNA \\
\hline South Tipperary & St Michael's Unit, South Tipperary General Hospital & $\sqrt{ }$ & $\sqrt{ }$ & $\sqrt{ }$ \\
\hline \multicolumn{5}{|c|}{ Donegal, Sligo, Leitrim, West Cavan } \\
\hline Donegal & Acute Psychiatric Unit, Carnamuggagh & $\sqrt{ }$ & $\sqrt{ }$ & $\sqrt{ }$ \\
\hline Donegal & $\begin{array}{l}\text { St Conal's Hospital } \\
\text { (ceased to operate as an AC 18/06/2010) }\end{array}$ & NR & NR & NR \\
\hline Sligo/Leitrim & Ballytivnan Sligo/Leitrim Mental Health Services & $\sqrt{ }$ & $\sqrt{ }$ & $\sqrt{ }$ \\
\hline \multicolumn{5}{|c|}{ Mid-West (Limerick, North Tipperary, Clare) } \\
\hline Clare & $\begin{array}{l}\text { Acute Psychiatric Unit, Midwestern Regional Hospital, } \\
\text { Ennis }\end{array}$ & $\sqrt{ }$ & $\sqrt{ }$ & $\sqrt{ }$ \\
\hline Clare & Cappahard Lodge & DNA & DNA & DNA \\
\hline Clare & Orchard Grove & DNA & DNA & DNA \\
\hline Limerick & Acute Psychiatric Unit 5B, Midwestern Regional Hospital & $\sqrt{ }$ & $\sqrt{ }$ & $\sqrt{ }$ \\
\hline Limerick & St Joseph's Hospital & DNA & DNA & DNA \\
\hline Limerick & $\begin{array}{l}\text { Tearmann Ward and Curragour Ward, St Camillus' } \\
\text { Hospital }\end{array}$ & DNA & DNA & DNA \\
\hline \multicolumn{5}{|c|}{ West (Galway, Mayo and Roscommon) } \\
\hline East Galway & St Brigid's Hospital, Ballinasloe & $\sqrt{ }$ & $\sqrt{ }$ & $\sqrt{ }$ \\
\hline Mayo & Adult Mental Health Unit, Mayo General Hospital & $\sqrt{ }$ & $\sqrt{ }$ & $\sqrt{ }$ \\
\hline Mayo & An Coillín & DNA & DNA & DNA \\
\hline Mayo & St Anne's Unit, Sacred Heart Hospital & DNA & DNA & DNA \\
\hline Mayo & Teach Aisling & DNA & DNA & DNA \\
\hline Roscommon & Department of Psychiatry, County Hospital Roscommon & DNA & DNA & DNA \\
\hline West Galway & Psychiatric Unit, University College Hospital Galway & $\sqrt{ }$ & $\sqrt{ }$ & $\sqrt{ }$ \\
\hline West Galway & $\begin{array}{l}\text { Unit 9A, Merlin Park University Hospital } \\
\text { (ceased to operate as an AC on } 16 / 05 / 2010 \text { ) }\end{array}$ & DNA & DNA & DNA \\
\hline
\end{tabular}




\section{Table A1 continued}

\begin{tabular}{|c|c|c|c|c|}
\hline Catchment Area & Approved Centre Name & 2008 Data Type & 2009 Data Type & 2010 Data Type \\
\hline \multicolumn{5}{|c|}{ Child and Adolescent Services } \\
\hline $\begin{array}{l}\text { Child and } \\
\text { Adolescent Service }\end{array}$ & St Anne's Child and Adolescent Unit & NR & DNA & DNA \\
\hline $\begin{array}{l}\text { Child and } \\
\text { Adolescent Service }\end{array}$ & Warrenstown Child \& Adolescent Inpatient Unit & DNA & DNA & DNA \\
\hline $\begin{array}{l}\text { Child and } \\
\text { Adolescent Service }\end{array}$ & Adolescent Un-patient Unit, St Vincent's Hospital & - & NR & NR \\
\hline $\begin{array}{l}\text { Child and } \\
\text { Adolescent Service }\end{array}$ & $\begin{array}{l}\text { Child and Adolescent Mental Health In-patient Unit, St } \\
\text { Stephen's Hospital }\end{array}$ & $\mathrm{N} / \mathrm{A}$ & DNA & DNA \\
\hline \multicolumn{5}{|c|}{ National Forensic Service } \\
\hline $\begin{array}{l}\text { National Forensic } \\
\text { Service }\end{array}$ & Central Mental Hospital & NR & Ref O/AC & Ref O/AC \\
\hline \multicolumn{5}{|c|}{ National Intellectual Disability Service } \\
\hline $\begin{array}{l}\text { National } \\
\text { Intellectual } \\
\text { Disability Service }\end{array}$ & St Joseph's Intellectual Disability Services, St Ita's Hospital & DNA & DNA & DNA \\
\hline \multicolumn{5}{|c|}{ Independent Service Providers } \\
\hline N/A & $\begin{array}{l}\text { Bloomfield Care Centre - Bloomfield, Kylemore, } \\
\text { Owendoher \& Swanbrook Wings }\end{array}$ & DNA & DNA & DNA \\
\hline N/A & Hampstead Private Hospital & NR & NR & DNA \\
\hline N/A & Highfield Private Hospital & NR & NR & DNA \\
\hline N/A & $\begin{array}{l}\text { Kylemore Clinic } \\
\text { (ceased to operate as an AC on 06/05/2009) }\end{array}$ & DNA & DNA & - \\
\hline N/A & $\begin{array}{l}\text { Lois Bridges } \\
\text { (entered on register of approved centres on 19/01/2010) }\end{array}$ & - & - & DNA \\
\hline $\mathrm{N} / \mathrm{A}$ & Palmerstown View, Stewart's Hospital & DNA & DNA & DNA \\
\hline N/A & St Edmundsbury Hospital & DNA & DNA & Ref $O / A C$ \\
\hline N/A & St John of God Hospital Limited & $\sqrt{ }$ & $\sqrt{ }$ & $\sqrt{ }$ \\
\hline N/A & St Patrick's University Hospital & $\sqrt{ }$ & $\sqrt{ }$ & $\sqrt{ }$ \\
\hline N/A & $\begin{array}{l}\text { Willow Grove Adolescent Unit, St Patrick's University } \\
\text { Hospital } \\
\text { (entered on register of approved centres on 30/04/2010) }\end{array}$ & - & - & DNA \\
\hline
\end{tabular}

\section{Abbreviations used in Table A1:}

$\sqrt{ }=$ Positive data returns (indicated that had administered one or more programmes of ECT)

$\mathbf{N R}=$ Nil returns (indicated zero administration of ECT)

DNA = Do not administer (indicated that they do not administer ECT in their centre)

Ref $\mathrm{O} / \mathrm{AC}=$ Patients referred to another approved centre for administration of ECT and data reported by the approved centre that administered ECT

- Approved centre not operating at the time 


\section{Appendix 3 - Population by Super-Catchment Area}

\begin{tabular}{|l|l|}
\hline Super Catchment Area & Population \\
\hline Dun Laoghaire/Dublin South-East \& Wicklow & 372,107 \\
\hline Dublin West/South West \& South City & 389,750 \\
\hline Kildare/West Wicklow/Laois/Offaly/Longford \& Westmeath & 457,244 \\
\hline Cavan/Monaghan/Louth \& Meath & 390,636 \\
\hline Dublin North & 222,049 \\
\hline Dublin North Central \& North West & 312,472 \\
\hline North Lee \& North Cork & 248,470 \\
\hline South Lee/West Cork \& Kerry & 372,660 \\
\hline Waterford \& Wexford & 255,593 \\
\hline Carlow/Kilkenny \& South Tipperary & 205,245 \\
\hline Donegal/Sligo/Leitrim \& West Cavan & 238,317 \\
\hline Mid-West & 361,028 \\
\hline West & 414,277 \\
\hline Total & $\mathbf{4 , 2 3 9 , 8 4 8}$ \\
\hline
\end{tabular}




\section{Appendix 4 - ICD 10 Codes and Diagnostic Groups}

\begin{tabular}{|l|l|}
\hline ICD-10 diagnostic groups & ICD-10 Code \\
\hline 1. Organic disorders & F00-F09 \\
\hline 2. Alcoholic disorders & F10 \\
\hline 3. Other drug disorders & F11-F19, F55 \\
\hline $\begin{array}{l}\text { 4. Schizophrenia, schizotypal and delusional } \\
\text { disorders }\end{array}$ & F20-F29 \\
\hline 5. Depressive disorders & F31.3, F31.4, F31.5, F32, F33, F34.1, F34.8, F34.9 \\
\hline 6. Mania & F30, F31.0, F31.1, F31.2, F31.6, F31.7, F31.8, F31.9, F34.0 \\
\hline 7. Neuroses & F40-F48 \\
\hline 8. Eating disorders & F50 \\
\hline 9. Personality and behavioural disorders & F60-F69 \\
\hline 10. Intellectual disability & F70-F79 \\
\hline $\begin{array}{l}\text { 11. Development disorders } \\
\text { 12. Behavioural and emotional disorders of } \\
\text { childhood }\end{array}$ & F80-F89-F98 \\
\hline $\begin{array}{l}\text { 13. Other diagnosis } \\
\text { 14. Unrecorded }\end{array}$ & F38, F39, F51-F54, F59, F99 \\
\hline
\end{tabular}

*ICD-10 codes were summarised into 14 categories for ease of presentation. Diagnostic categories used are as per HRB coding (Daly and Walsh, 2006) however residents without a diagnosis assigned are separated out from the HRB category Other and Unspecified. 


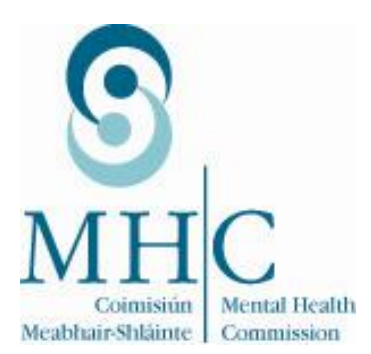

Mental Health Commission Coimisiún Meabhair-Shláinte St. Martin's House,

Waterloo Road, Dublin 4

Telephone: 016362400

Fax: $\quad 016362440$

Email:_info@mhcirl.ie

Web: www.mhcirl.ie 